\title{
Binuclear Complexes and Extended Chains Featuring Pt" Influence of the Pyridine-2-Thiolate and Cyclometalated Ligands on the Self-Assembly and Luminescent Behavior
}

\author{
Jesús R. Berenguer, ${ }^{\dagger}$ Elena Lalinde, ${ }^{* \dagger}$ Antonio Martín, ${ }^{\ddagger}$ M. Teresa Moreno, ${ }^{*}{ }^{\dagger}$ Sergio Sánchez, ${ }^{\S}$ \\ and Hamid R. Shahsavari ${ }^{\dagger, \|}$ \\ ${ }^{\dagger}$ Departamento de Química, Centro de Síntesis Química de La Rioja, Universidad de La Rioja, Logroño 26006, Spain \\ ${ }^{\ddagger}$ Departamento de Química Inorgánica, Instituto de Síntesis Química y Catálisis Homogénea. Universidad de Zaragoza, CSIC, \\ Zaragoza 50009, Spain \\ ${ }^{\S}$ School of Chemistry, University of Manchester, Oxford Road, Manchester M13 9PL, U.K. \\ "Department of Chemistry, Institute for Advanced Studies in Basic Sciences, Yousef Sobouti Boulevard, Zanjan 45195-1159, Iran
}

\section{Supporting Information}

\begin{abstract}
Platinum solvate complexes $\left[\mathrm{Pt}\left(\mathrm{C}_{6} \mathrm{~F}_{5}\right)\left(\mathrm{C}^{\wedge} \mathrm{N}\right)(\mathrm{S})\right]\left[\mathrm{C}^{\wedge} \mathrm{N}=\right.$ phenylpyridinyl (ppy), $\mathrm{S}=$ dimethyl sulfoxide (DMSO) (A); $\mathrm{C}^{\wedge} \mathrm{N}=$ benzoquinolinyl (bzq), $\mathrm{S}$ $\left.=\mathrm{CH}_{3} \mathrm{COCH}_{3}(\mathbf{B})\right]$ react with $[\mathrm{Tl}(\mathrm{Spy})]$ (Spy = 2-pyridinethiolate) to afford binuclear $\left[\left\{\mathrm{Pt}\left(\mathrm{C}_{6} \mathrm{~F}_{5}\right)\left(\mathrm{C}^{\wedge} \mathrm{N}\right)\right\} \mathrm{Tl}(\mathrm{Spy})\right]\left[\mathrm{C}^{\wedge} \mathrm{N}=\right.$ ppy $(\mathbf{1})$ and bzq $\left.(2)\right]$ species containing a $\mathrm{Pt}-\mathrm{Tl}$ bonding interaction, supported by a $\mu$-Spy- $\kappa \mathrm{N}, \mathrm{S}$ bridging ligand, as confirmed by X-ray diffraction. However, the related reactions with $\left[\mathrm{Tl}\left(\mathrm{SpyCF}_{3}-5\right)\right]\left[\mathrm{SpyCF}_{3}-5=5\right.$ (trifluoromethyl)-2-pyridinethiolate $]$ give neutral extended chains $\left[\left\{\mathrm{Pt}\left(\mathrm{C}_{6} \mathrm{~F}_{5}\right)\left(\mathrm{C}^{\wedge} \mathrm{N}\right)\right\}\right.$ $\left.\mathrm{Tl}\left(\mathrm{SpyCF}_{3}-5\right)\right]_{n}\left[\mathrm{C}^{\wedge} \mathrm{N}=\right.$ ppy (3) and bzq (4)]. 3 features a zigzag $-\mathrm{Pt}-\mathrm{Tl} \cdots \mathrm{S}-\mathrm{Pt}-$ chain, generated by $\mathrm{Pt}-\mathrm{Tl}$ and $\mathrm{Tl} \cdots \mathrm{S}$ bonds, with the $\mathrm{SpyCF}_{3}$ acting as a $\mu-\kappa \mathrm{N}: \kappa^{2} \mathrm{~S}$ bridging ligand, whereas 4 displays an unsupported $\cdots \mathrm{Tl}-\mathrm{Pt} \cdots \mathrm{Tl}-\mathrm{Pt} \cdots$ backbone (angle of ca. $158.7^{\circ}$ ). The lowest-energy absorption bands in the UV-vis spectra in $\mathrm{CH}_{2} \mathrm{Cl}_{2}$, associated with ${ }^{1} \mathrm{~L}^{\prime} \mathrm{LCT}$ transitions with minor ${ }^{1} \mathrm{LC} /{ }^{1} \mathrm{MLCT}\left(\mathrm{L}^{\prime}=\mathrm{Spy}\right.$ or $\mathrm{SpyCF}_{3}-5$; $\mathrm{L}$ $=\mathrm{C}^{\wedge} \mathrm{N}$ ) character, are similar for all complexes 1-4, demonstrating that for $\mathbf{3}$ and $\mathbf{4}$ the chains break down in solution to yield similar bimetallic Pt-Tl units. For 2, two different forms, 2-o (orange) and 2-y (yellow), exhibiting different colors and emissions were found depending on the isolation conditions. Slow crystallization favors formation of the thermodynamically more stable yellow form (2-y), which exhibits a high-energy (HE) structured emission band, whereas fast crystallization gives rise to the orange form (2-o), with a remarkably lower energy structureless emission. Complexes 1 and 3 exhibit dual luminescence in the solid state at $298 \mathrm{~K}$ : an unstructured low-energy band associated with ${ }^{3} \pi \pi^{*}$ excimeric emission due to $\pi \cdots \pi\left(\mathrm{C}^{\wedge} \mathrm{N}\right)$ interactions and a more structured $\mathrm{HE}$ band, assigned, with support of density functional theory calculations, to an intraligand ${ }^{3} \mathrm{LC}\left(\mathrm{C}^{\wedge} \mathrm{N}\right)$ excited state mixed with some ligand (SPy)/platinum-to-ligand $\left(\mathrm{C}^{\wedge} \mathrm{N}\right)^{3}\left[\left(\mathrm{~L}^{\prime}+\mathrm{M}\right) \mathrm{LCT}\right]$ charge transfer. Chain 4 only shows a $\mathrm{HE}$ band at $298 \mathrm{~K}$, attributed to a ${ }^{3} \mathrm{~L}^{\prime} \mathrm{LCT}$ ( $\mathrm{SpyCF}_{3} \rightarrow$ bzq) excited state mixed with a minor ${ }^{3} \mathrm{MLCT} /{ }^{3} \mathrm{MM}^{\prime} \mathrm{CT}\left(\mathrm{M}=\mathrm{Pt} ; \mathrm{M}^{\prime}=\mathrm{Tl}\right)$ contribution. At $77 \mathrm{~K}$, the $\pi \pi^{*}$-stacking emission is predominant in all complexes, except in the form 2-y. Interestingly, 2-4 exhibit reversible mechanochromic color and luminescence changes, with remarkable red shift and increased quantum yields, and upon exposure to solvents, they are restored to their original color and emission. On the basis of powder X-ray diffraction studies, a plausible mechanism of the mechanochromic processes is proposed, involving reversible crystalline-to-amorphous phase transitions.
\end{abstract}

\section{INTRODUCTION}

Closed- and sub-closed-shell interactions and metal-metal dative bonds have been used as powerful tools in the range of heteronuclear discrete clusters and supramolecular architectures. ${ }^{1}$ In addition to the particular characteristics of the chemical bonding in these complexes, these kinds of heterometallic systems are of interest because of their photophysical properties, in particular their very efficient luminescence. ${ }^{2}$ Many studies have shown that their emission properties depend on the nature of the metals, the coligands, the strength of the metal-metal and ligand-ligand interactions, and the secondary contacts. Therefore, many of these materials exhibit a great variety of tunable photoluminescent, mechanochromic, vapochromic, or vapoluminescent properties, with extensive applications as photofunctional materials. ${ }^{3}$

Over the past few years, a great number of $\mathrm{Pt}^{\mathrm{II}} \mathrm{d}^{8}$ with closed-shell $d^{101 d, 2 a, b, f, 4}$ and, to a lesser extent, with $d^{10} s^{2}$ heavy metals $\left(\mathrm{Tl}^{\mathrm{I}}\right.$ and $\left.\mathrm{Pb}^{\mathrm{II}}\right)$ have been reported. With regard to these latter systems, the number of luminescent heteropolymetallic

Received: March 21, 2016

Published: August 4, 2016 
Scheme 1. Synthetic Routes for the Pt-Tl Complexes 1-4

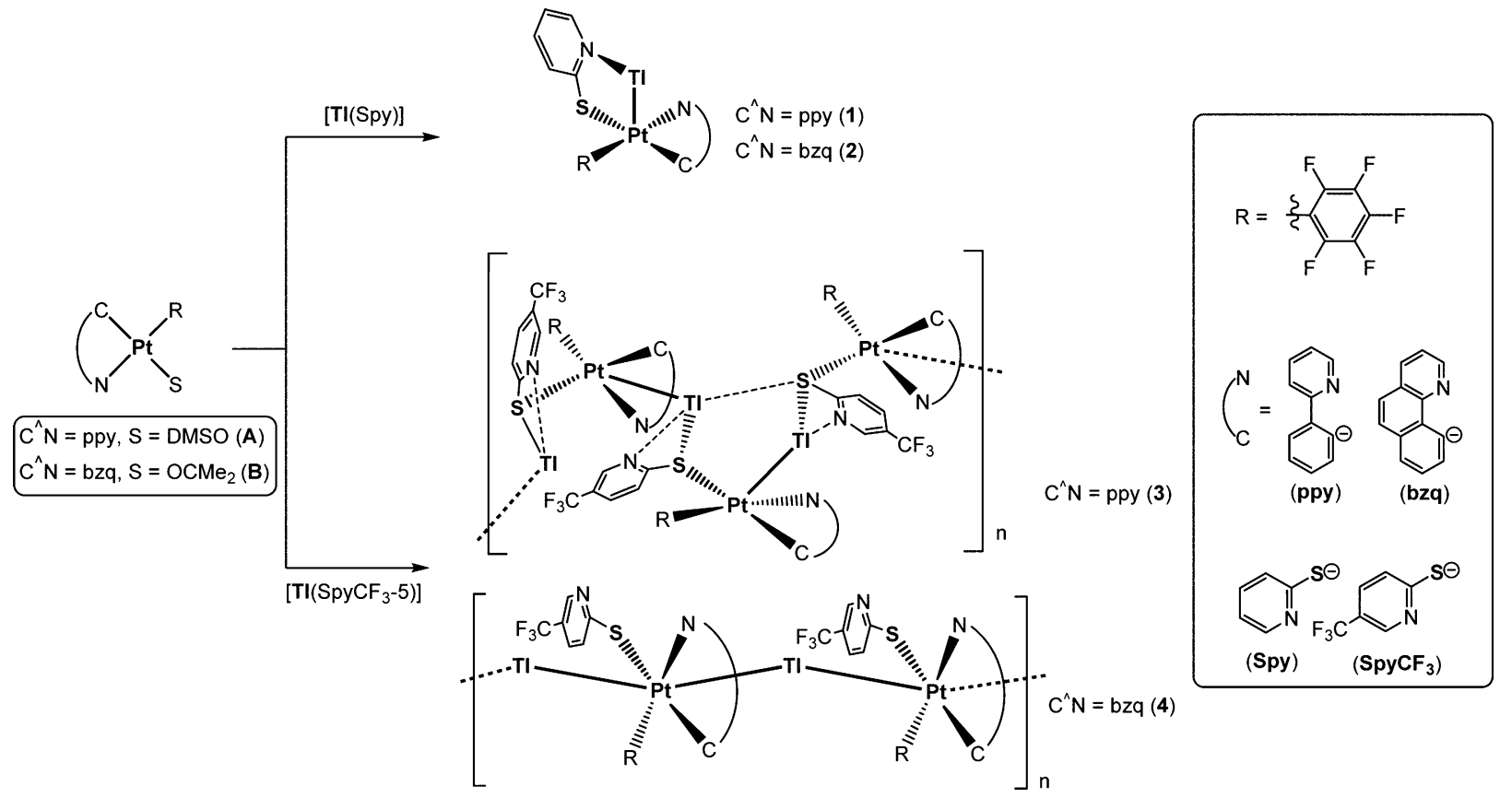

systems involving metallophilic interactions with $\mathrm{Pb}^{\mathrm{II}}$ is quite limited. ${ }^{5}$ However, since the pioneering contribution of the first luminescent complex $\left[\mathrm{Tl}_{2} \mathrm{Pt}(\mathrm{CN})_{4}\right]^{6},{ }^{6}$ several interesting families of heteropolynuclear $\mathrm{Pt}^{\mathrm{II}}-\mathrm{Tl}^{\mathrm{I}}$ clusters have been reported. These clusters show diverse structural configurations, supported or unsupported by bridging ligands, including dinuclear (PtTl), ${ }^{7}$ trinuclear $\left(\mathrm{PtTl}_{2},{ }^{8} \mathrm{Pt}_{2} \mathrm{Tl}^{5,, 9}\right)$, tetranuclear [paired $(\mathrm{PtTl})_{2}{ }^{7 \mathrm{a}, 10}$ and trigonal $\left.\left(\mathrm{Pt}_{3} \mathrm{Tl}\right)^{11}\right]$, and hexanuclear $\left(\mathrm{Pt}_{2} \mathrm{Tl}_{4}{ }^{10 c, 12}\right.$ and $\left.\mathrm{Pt}_{3} \mathrm{Tl}_{3}{ }^{11 b}\right)$ clusters or infinite networks. ${ }^{5 e, 9 a, c, 10 b, c, 13}$ In the Pt $\mathrm{d}^{10} \mathrm{~s}^{2}$ systems, the stereoactivity of the $6 \mathrm{~s}^{2}$ lone pair of the heavy ion $\left(\mathrm{Tl}^{\mathrm{I}}\right.$ and $\left.\mathrm{Pb}^{\mathrm{II}}\right)$ usually exerts a remarkable influence on the final structure of the cluster. ${ }^{14}$

In this area, work from our research group has demonstrated the utility of lead pyridinethiolates $\left(\left[\mathrm{Pb}(\mathrm{Spy})_{2}\right] \quad(\mathrm{Spy}=2\right.$ pyridinethiolate $)$ and $\left.\left[\mathrm{Pb}\left(\mathrm{SpyCF}_{3}-5\right)_{2}\right]\right) \quad\left[\mathrm{SpyCF}_{3}-5=5-\right.$ (trifluoromethyl)-2-pyridinethiolate] and neutral cycloplatinate solvate complexes $\left[\mathrm{Pt}\left(\mathrm{C}_{6} \mathrm{~F}_{5}\right)\left(\mathrm{C}^{\wedge} \mathrm{N}\right)(\mathrm{S})\right]\left[\mathrm{C}^{\wedge} \mathrm{N}=\right.$ phenylpyridinyl (ppy), $\mathrm{S}=$ dimethyl sulfoxide (DMSO) $(\mathbf{A}) ; \mathrm{C}^{\wedge} \mathrm{N}$ = benzoquinolinyl (bzq), $\mathrm{S}=\mathrm{CH}_{3} \mathrm{COCH}_{3}$ (B)] to form very stable $\mathrm{Pt}_{2} \mathrm{~Pb}$ clusters featuring two distinct $\mathrm{Pt}-\mathrm{Pb}$ bonds, supported by different bridging pyridinethiolate ligands. ${ }^{15}$ In addition, they exhibit different stimulus-responsive luminescence and color switches, arising from subtle changes in the sterochemical activity of the lone pair around the $\mathrm{Pb}^{\mathrm{II}}$ center. Intrigued by their structural variety and distinct luminescence behavior, we decided to study the role of the heterometal in the structures and photophysical behavior of these heteropolymetallic systems. In this work, we demonstrate the ability of thallium pyridinethiolate to form heterometallic aggregates featuring supported and unsupported $\mathrm{Pt}-\mathrm{Tl}$ metal-metal linkages. Thus, $[\mathrm{TlSpy}]$ and the solvates $\left[\mathrm{Pt}\left(\mathrm{C}_{6} \mathrm{~F}_{5}\right)\left(\mathrm{C}^{\wedge} \mathrm{N}\right)(\mathrm{S})\right]$ form binuclear species $\left[\left\{\mathrm{Pt}\left(\mathrm{C}_{6} \mathrm{~F}_{5}\right)\left(\mathrm{C}^{\wedge} \mathrm{N}\right)\right\} \mathrm{Tl}(\mathrm{Spy})\right]\left[\mathrm{C}^{\wedge} \mathrm{N}=\right.$ ppy (1) and bzq (2)] with $\mu$-Spy- $\kappa \mathrm{N}, S$ bridging groups, whereas in the case of $\left[\mathrm{Tl}\left(\mathrm{SpyCF}_{3}-5\right)\right], 1 \mathrm{D}$ extended arrays are formed based on unsupported $\mathrm{Pt}-\mathrm{Tl}\left[\mathrm{C}^{\wedge} \mathrm{N}=\right.$ bzq (4) $]$ or a combination of $\mathrm{Pt}-\mathrm{Tl}$ bonds and secondary $\mathrm{Tl} \cdots \mathrm{S}$ linkages $\left[\mathrm{C}^{\wedge} \mathrm{N}=\right.$ ppy (3)]. Luminescence studies supported by computational calculations and powder X-ray diffraction (PXRD) analysis are also presented.

\section{RESULTS AND DISCUSSION}

Synthesis and Structural Characterization. As depicted in Scheme 1 , the reaction of platinum solvate complexes $\left[\mathrm{Pt}\left(\mathrm{C}_{6} \mathrm{~F}_{5}\right)\left(\mathrm{C}^{\wedge} \mathrm{N}\right)(\mathrm{S})\right]\left[\mathrm{C}^{\wedge} \mathrm{N}=\right.$ ppy, $\mathrm{S}=\operatorname{DMSO}(\mathbf{A}) ;{ }^{15 \mathrm{~b}} \mathrm{C}^{\wedge} \mathrm{N}=$ bzq, $\left.\mathrm{S}=\mathrm{CH}_{3} \mathrm{COCH}_{3}(\mathbf{B})^{16}\right]$ with 1 equiv of in situ freshly prepared $[\mathrm{Tl}(\mathrm{Spy})]$ or $\left[\mathrm{Tl}\left(\mathrm{Spy}_{-} \mathrm{CF}_{3}-5\right)\right]$, formed by the reaction of $[\mathrm{Tl}(\mathrm{acac})]$ and the appropriate pyridine-2-thiol ligand in a 1:1 molar ratio (Experimental Section), gives the bimetallic species $\left[\left\{\mathrm{Pt}\left(\mathrm{C}_{6} \mathrm{~F}_{5}\right)\left(\mathrm{C}^{\wedge} \mathrm{N}\right)\right\} \mathrm{Tl}(\mathrm{Spy})\right]\left[\mathrm{C}^{\wedge} \mathrm{N}=\right.$ ppy $(\mathbf{1})$ and bzq $(2)]$ or the extended chains $\left[\left\{\mathrm{Pt}\left(\mathrm{C}_{6} \mathrm{~F}_{5}\right)\left(\mathrm{C}^{\wedge} \mathrm{N}\right)\right\} \mathrm{Tl}-\right.$ $\left.\left(\mathrm{SpyCF}_{3}-5\right)\right]_{n}\left[\mathrm{C}^{\wedge} \mathrm{N}=\right.$ ppy $(3)$ and bzq $\left.(4)\right]$, respectively.

All complexes 1-4 were characterized by standard analytical and spectroscopic techniques, and their integrity in solution was confirmed by multinuclear $\left[{ }^{1} \mathrm{H},{ }^{19} \mathrm{~F}\right.$, and ${ }^{13} \mathrm{C}\left\{{ }^{1} \mathrm{H}\right\}$ $\left.\left(\mathrm{CD}_{3} \mathrm{COCD}_{3}\right)\right]$ NMR spectroscopy. The assignments were made on the basis of $2 \mathrm{D}$ experiments, and schematic labeling is given in Figure S1. Their MALDI $(+)$ spectra exhibit the molecular peaks associated with $[\mathrm{M}]^{+}$or $[\mathrm{M}+\mathrm{Tl}]^{+}$fragments, suggesting the integrity of bimetallic units in solution. The NMR spectra of all complexes show signals for only one type of cyclometalated $\mathrm{C}_{6} \mathrm{~F}_{5}$ and $\mathrm{Spy} / \mathrm{SpyCF}_{3}-5$ ligands, corresponding to " $\mathrm{Pt}\left(\mathrm{C}_{6} \mathrm{~F}_{5}\right)\left(\mathrm{C}^{\wedge} \mathrm{N}\right) \mathrm{Tl}(\mu$-Spy)" fragments, in spite of the different environments observed in the solid state. Their ${ }^{19} \mathrm{~F}$ NMR spectra in $\mathrm{CD}_{3} \mathrm{COCD}_{3}$ display the common $\mathrm{AA}^{\prime} \mathrm{MX}^{\prime} \mathrm{X}$ spin system $\left(2 \mathrm{~F}^{o}, \mathrm{~F}^{p}\right.$, and $\left.2 \mathrm{~F}^{m}\right),{ }^{15 \mathrm{~b}}$ indicating that the $\mathrm{C}_{6} \mathrm{~F}_{5}$ group has free rotation around the $\mathrm{Pt}-\mathrm{C}_{\mathrm{ipso}}\left(\mathrm{C}_{6} \mathrm{~F}_{5}\right)$ bond. The $o$-F signal appears flanked by satellites with a decrease in the ${ }^{19} \mathrm{~F}-{ }^{195} \mathrm{Pt}$ coupling constant $\left(J_{\mathrm{Pt}, \mathrm{F}^{\circ}}=401-422 \mathrm{~Hz}\right)$ with respect to the starting platinum solvate complexes $(494 \mathrm{~Hz}, \mathrm{~A} ; 501 \mathrm{~Hz}$, B). ${ }^{15 b, 16}$ This reduction in the coupling constants has been related to the increase in the coordination number of the platinum center as a result of the formation of a donor $\mathrm{Pt} \rightarrow \mathrm{Tl}$ bond. $^{5 e, 9 a, 10 b, 17}$

It is worth noting that two different polymorphs with distinctive color and emission were found for $\mathbf{2}$ depending on 
the crystallization conditions. Kinetic conditions, i.e., fast precipitation by the addition of $n$-hexane to $\mathrm{CH}_{2} \mathrm{Cl}_{2}$ or acetone solutions of 2, give an orange solid (form 2-o). However, slow precipitation or crystallization from the desired solvent $\left(\mathrm{CH}_{2} \mathrm{Cl}_{2}\right.$ or acetone) affords a yellow solid (form 2-y). Yellow crystals of 1 and 2-y were obtained by the slow diffusion of $n$ hexane into solutions of complex $\mathbf{1}$ in acetone or complex $\mathbf{2}$ in $\mathrm{CH}_{2} \mathrm{Cl}_{2}$ at $-30{ }^{\circ} \mathrm{C}$ (crystals of 2 -y obtained slowly from acetone $/ n$-hexane at $-30{ }^{\circ} \mathrm{C}$ show an almost identical structure; to simplify, the data used for this work are of crystals from $\mathrm{CH}_{2} \mathrm{Cl}_{2} / n$-hexane). Unfortunately, crystallization conditions (slow process) prevent one from obtaining orange crystals of 2-o.

The crystal structures of complexes 1 and 2-y (Figures 1, 2, and S2-S4 and Tables 1 and S1 and S2) were confirmed by X-

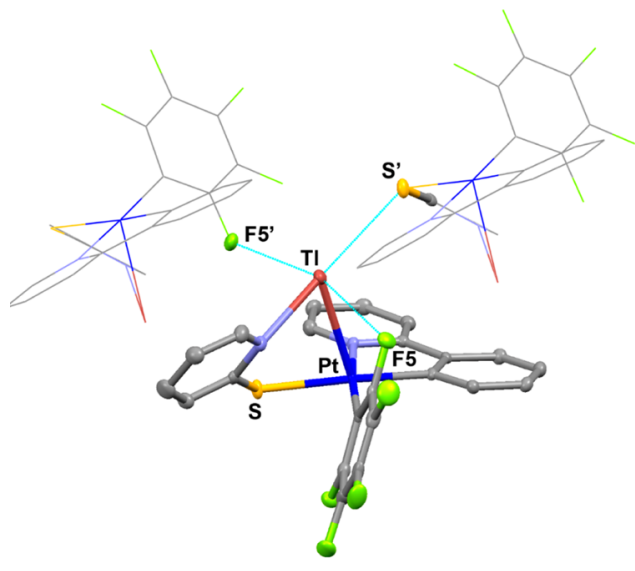

Figure 1. Molecular structure of $\mathbf{1}$ showing the environment of the $\mathrm{Tl}^{\mathrm{I}}$ center. Asymmetric unit and selected atoms shown as $50 \%$ probability thermal ellipsoids.

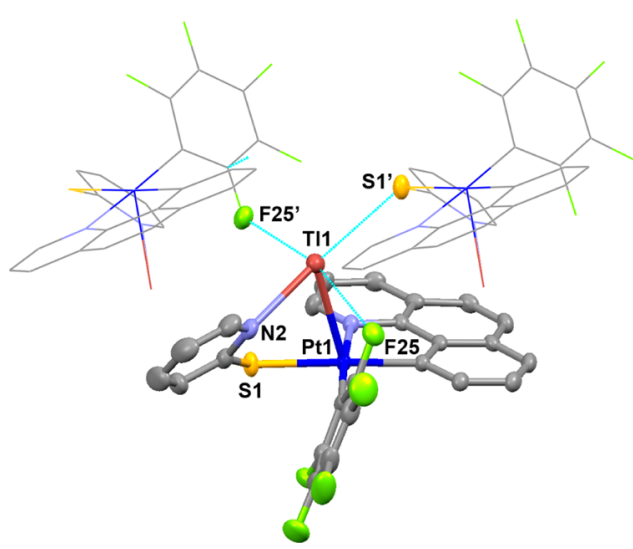

Figure 2. Molecular structure of $\left[\left\{\mathrm{Pt}\left(\mathrm{C}_{6} \mathrm{~F}_{5}\right)(\mathrm{bzq})\right\} \mathrm{Tl}(\mathrm{Spy})\right]$ (2-y) showing the environment of the $\mathrm{Tl}^{\mathrm{I}}$ center. Asymmetric unit and selected atoms shown as $50 \%$ probability thermal ellipsoids.

ray diffraction. Both crystallize in the same space group (P21/ $n)$ of the monoclinic system. The X-ray studies confirm the formation of bimetallic " $\mathrm{PtTl}\left(\mathrm{C}_{6} \mathrm{~F}_{5}\right)\left(\mathrm{C}^{\wedge} \mathrm{N}\right)($ Spy)" units, containing a donor-acceptor $\mathrm{Pt}^{\mathrm{II}} \rightarrow \mathrm{Tl}^{\mathrm{I}}$ bond, with intermetallic distances of 2.8848(2) $\AA$ (1) and 2.8957(2) $\AA$ (2). These bond lengths are in the lower range of $\mathrm{Pt}^{\mathrm{II}}-\mathrm{Tl}^{\mathrm{I}}$ bond distances, ${ }^{5 e, 8 b, 9 a, c, 10 b, d, e, 11,13,18}$ comparable to the sum of the metallic radii of $\mathrm{Pt}$ and $\mathrm{Tl}$ atoms $(2.99 \AA)$, and similar to those reported in related bimetallic $\mathrm{Pt}^{\mathrm{II}} \rightarrow \mathrm{Tl}^{\mathrm{I}}$ species, such as
$[\mathrm{PtMe}(\mathrm{bzq})(\mathrm{dppy}) \mathrm{Tl}] \mathrm{PF}_{6} \quad[$ dppy $=2$-(diphenylphosphino $)-$ pyridine, $2.8914(2) \AA]^{17 a}$ or $\left[\mathrm{PtTl}(\right.$ bzq $\left.)\left(\mathrm{C} \equiv \mathrm{CC}_{5} \mathrm{H}_{4} \mathrm{~N}-2\right)_{2}\right]$ $[2.9266(12) \AA] .{ }^{7 \mathrm{a}}$ The $\mathrm{Pt}^{\mathrm{II}}-\mathrm{Tl}^{\mathrm{I}}$ vector is nearly perpendicular to the square-planar basal plane [tilted by $14.0(1)^{\circ}(1)$ and $12.8(1)^{\circ}$ (2) with respect to the normal line of the coordination plane].

The $\mathrm{Pt}-\mathrm{Tl}$ core is supported by a $(\mu-\kappa N, S)$-pyridine-2thiolate $\left(\mathrm{Spy}^{-}\right)$bridging ligand, ${ }^{19}$ with the $\mathrm{Tl}^{\mathrm{I}}$ atom bonded to the $\mathrm{N}$ atom [Tl-N2 2.634(3) $\AA$ (1), 2.674(4) $\AA(2)]$ and the $\mathrm{Pt}^{\mathrm{II}}$ atom to the $\mathrm{S}$ atom [Pt-S 2.3878(10) $\AA$ (1), 2.3867(10) $\AA$ (2)], with the distances being within the range reported for these types of bonds. ${ }^{15,20}$ The $\mathrm{Tl}$ center completes its coordination with a short intramolecular contact with one $o-\mathrm{F}$ atom [F5 2.974(1) $\AA$ (1); F25 3.008(3) $\AA$ (2)] and two additional long secondary intermolecular interactions with another $o-\mathrm{F}$ and a $\mathrm{S}$ center of two neighboring binuclear units. These intermolecular $\mathrm{Tl} \cdots \mathrm{F}^{\prime}$ [3.133(7) (1), 3.081(3) Å (2)] and $\mathrm{Tl} \cdots \mathrm{S}^{\prime}$ distances $\left[3.2991(1)(1), 3.281(1) \AA \mathrm{A}^{2}(2)\right]$ are rather long but close to the sum of the covalent radii of $\mathrm{Tl}^{\mathrm{I}}(1.55 \AA)$ and the van der Waals radii of the F $(1.47 \AA)$ and $\mathrm{S}(1.80 \AA)$ atoms, respectively. ${ }^{21}$ As shown in Figures S3 and S4, these secondary interactions together with $\pi \cdots \pi\left(\mathrm{C}^{\wedge} \mathrm{N}\right)$-stacking interactions $^{5 e, 16,18,21}$ [interplanar distances: 3.392(1) $\AA$ (1) and 3.392(6) $\AA$ (2)] form 2D framework structures.

Different crystallographic structures have been obtained by incorporating the $\mathrm{CF}_{3}$ substituent on the thiolate ligand, which lead to distinct luminescence properties (Figures 3, 4, and S2, S5, and S6 and Tables 1 and S3 and S4). As shown in Figure 3, complex 3 involves an unusual $1 \mathrm{D}[-\mathrm{Pt}-\mathrm{Tl}-\mathrm{S}-\mathrm{Pt}-]$ zigzag chain, formed by linking a square-planar " $\mathrm{Pt}\left(\mathrm{C}_{6} \mathrm{~F}_{5}\right)(\mathrm{ppy})$ $\left(\mathrm{SpyCF}_{3}-5\right)$ " unit to two $\mathrm{Tl}^{\mathrm{I}}$ centers: one through a donor $\mathrm{Pt}^{\mathrm{II}}$ $\rightarrow \mathrm{Tl}^{\mathrm{I}}$ bond $[3.0924(2) \AA]$ and the other through the $\mathrm{S}$ atom of the pyridinethiolate group, which acts as a $\mu-\kappa \mathrm{N}: \kappa^{2} \mathrm{~S}$ bridging ligand. ${ }^{19}$ Thus, the $S$ atom is connected to the Pt center [Pt-S1 $2.4015(10) \AA]$ and to the $\mathrm{Tl}$ atom with a short Tl1-S1 distance $[2.9961(11) \AA]$. The $\mathrm{Tl}^{\mathrm{I}}$ center in the chain achieves a five coordination with a weak T11-N2 $[2.800(4) \AA]$ bond to the N atom of the $\mathrm{SpyCF}_{3}$ ligand, the $o$-F atom [3.047(3) $\AA$ ], and a relatively long contact to the $S$ atom of the next unit $\left[\mathrm{Tl} 1-\mathrm{S1}^{\prime}\right.$ 3.383(1) A]. Their crystal packing reveals the occurrence of extended $\pi \cdots \pi$ interactions $[3.332(6) \AA]$ in a head-to-tail fashion between ppy ligands of neighboring chains, assisted by secondary F...H-C [2.612(3) Å] (Figure S5).

Crystallographic characterization of 4 shows a $1 \mathrm{D}(\cdot \cdot[\cdot \mathrm{Tl}-$ $\mathrm{Pt} \cdot$. Tl-Pt...$)$ chain with alternating $" \mathrm{Pt}\left(\mathrm{C}_{6} \mathrm{~F}_{5}\right)(\mathrm{bzq})\left(\mathrm{SpyCF}_{3}-\right.$ $5)$ " and "Tl" fragments, which is maintained by unsupported $\mathrm{Pt}^{\mathrm{II}} \rightarrow \mathrm{Tl}^{\mathrm{I}}$ bonds (Figure 4). As far as we know, only three related linear chains without any supporting ligands have been reported previously, published by our group. ${ }^{5 e, 9 a, 10 c}$ In 4 , the $\mathrm{Pt}-\mathrm{Tl}$ distances are asymmetric, with a short $\mathrm{Pt}-\mathrm{Tl}$ distance $[3.1965(2) \AA]$ in the high range of those described for $\mathrm{Pt}^{\mathrm{II}}-\mathrm{Tl}^{\mathrm{I}}$ complexes ${ }^{5 e, 8 b, 9 a, c, 10 b, d, e, 11,13,18}$ and a significantly long Pt-Tl' distance $[3.4566(2) \AA]$. Each $\mathrm{Tl}^{\mathrm{I}}$ center is additionally surrounded by the $o-\mathrm{F}$ atoms of two $\mathrm{C}_{6} \mathrm{~F}_{5}$ ligands within the same chain $\left[\mathrm{Tl} \cdots \mathrm{F}_{o} 3.011(2)\right.$ and 3.2912(3) $\AA$ ] and by the $\mathrm{N}$ and $\mathrm{S}$ atoms of a thiolate group in an adjacent chain $[\mathrm{Tl} \cdots$ $\left.\mathrm{N}_{\mathrm{SpyCF}_{3}}^{\prime} 2.735(4) \AA ; \mathrm{Tl} \cdots \mathrm{S}_{\mathrm{SpyCF}_{3}}^{\prime} 3.0479(10) \AA\right]$, rendering a final $2 \mathrm{D}$ network. As in the related $\left[\left\{\mathrm{Pt}\left(\mathrm{C}_{6} \mathrm{~F}_{5}\right)_{2}(\mathrm{bzq})\right\} \mathrm{Tl}\right.$ $\left.\left(\mathrm{Me}_{2} \mathrm{CO}\right)\right]_{n}$, the chain is not linear, with $\mathrm{Pt}-\mathrm{Tl}-\mathrm{Pt}$ and $\mathrm{Tl}-$ $\mathrm{Pt}-\mathrm{Tl}$ angles of $\sim 158.7^{\circ}$. Curiously, in contrast to previous complexes 1-3, the $\mathrm{SpyCF}_{3}$ ligand is rather coplanar with the platinum coordination plane [dihedral angle $21.9(1)^{\circ}$ ], which 
Table 1. Selected Bond Lengths (Å) and Angles (deg) around the Tl Metal Center for 1-4

\begin{tabular}{|c|c|c|c|c|}
\hline & 1 & $2-y$ & 3 & 4 \\
\hline $\mathrm{Pt}-\mathrm{Tl}$ & $2.8848(2)$ & $2.8957(2)$ & $3.0924(2)$ & $3.1965(2)$ \\
\hline $\mathrm{Pt}-\mathrm{Tl}^{\prime}$ & & & & $3.4566(2)$ \\
\hline $\mathrm{Tl}-\mathrm{N} 2$ & $2.634(3)$ & $2.674(4)$ & $2.800(4)$ & $2.735(4)$ \\
\hline $\mathrm{Tl}-\mathrm{S}^{\prime}$ & $3.2991(1)$ & $3.281(1)$ & $2.9961(11), 3.383(1)$ & $3.0479(10)$ \\
\hline \multirow[t]{2}{*}{$\mathrm{Tl}-\mathrm{F}$} & F5: $2.974(1)$ & F25: $3.008(3)$ & F4: $3.047(3)$ & F5: 3.011(2) \\
\hline & $F 5^{\prime}: 3.133(7)$ & $\mathrm{F} 25^{\prime}: 3.081(3)$ & & $\mathrm{F1}^{\prime}: 3.2912(3)$ \\
\hline $\mathrm{N} 2-\mathrm{T} 1-\mathrm{Pt}$ & $78.63(7)$ & $78.00(8)$ & & \\
\hline $\mathrm{S}^{\prime}-\mathrm{Tl}-\mathrm{Pt}$ & & & $100.03(2)$ & \\
\hline $\mathrm{Pt}-\mathrm{Tl}-\mathrm{Pt}^{\prime}$ & & & & $158.735(8)$ \\
\hline $\mathrm{Tl}-\mathrm{Pt}-\mathrm{Tl}^{\prime}$ & & & & $158.733(8)$ \\
\hline
\end{tabular}
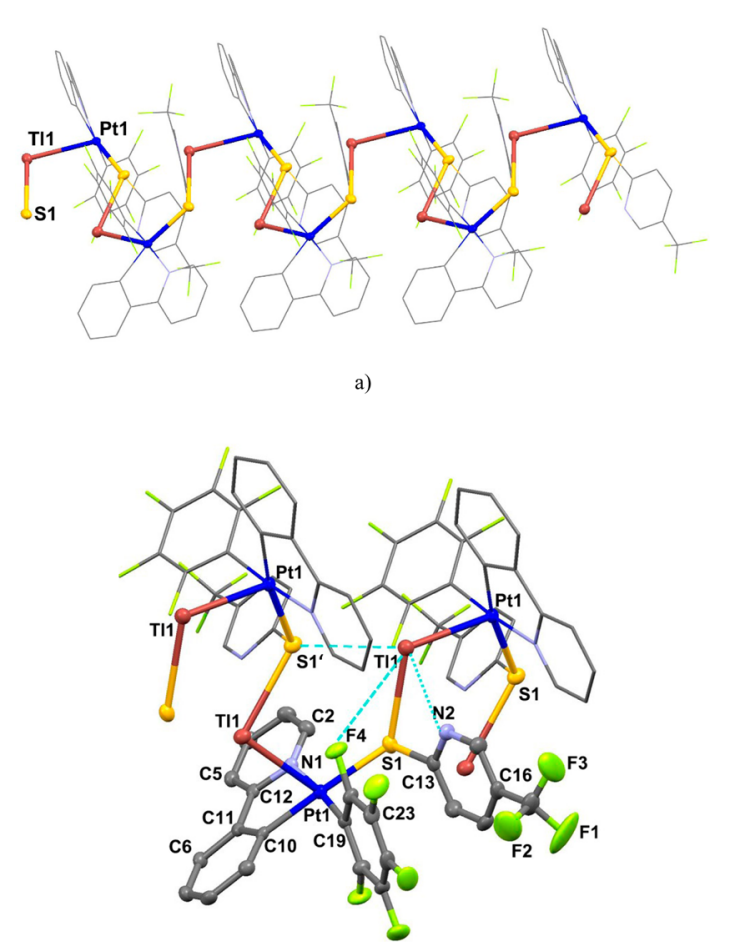

b)

Figure 3. (a) Supramolecular packing in 3 showing the metallic chain along the $b$ axis, related to other chains through $\pi \cdots \pi$ and $\mathrm{F} \cdots \mathrm{H}-\mathrm{C}$ interactions. (b) View of part of the chain showing the environment of the $\mathrm{Tl}^{\mathrm{I}}$ center. Asymmetric unit and selected atoms shown as $50 \%$ probability thermal ellipsoids.

favors the presence of extensive $\pi \cdots \pi$ stacking, not only between $\mathrm{Pt}(\mathrm{bzq})$ fragments of adjacent chains but also between the nitrogen-containing ring of bzq and the thiolate ligand $\left(\mathrm{SpyCF}_{3}\right)$ of adjacent chains, with interplanar distances in the range of 3.13-3.60 and 3.26-3.44 Å, respectively (Figure S6).

Photophysical Properties. Absorption Spectra. Electronic absorption data for 1-4 obtained in the solid state and in different solvents $\left(\mathrm{CH}_{2} \mathrm{Cl}_{2}\right.$ and acetone $)$ are collected in Table S5. In the solid state, the yellow solids (1, 2-y, 3, and 4) are characterized by broad absorption spectral bands up to 520$530 \mathrm{~nm}$ (Figure S7a), whereas the orange solid (2-o) shows an absorption spectrum extending to $600 \mathrm{~nm}$ (Figure S7b) in coherence with its color. The absorption above $450 \mathrm{~nm}$, which is absent in solution, is attributed to the presence of extensive aggregation in the solid state, mainly through strong $\pi \pi^{*}$ stacking interactions.

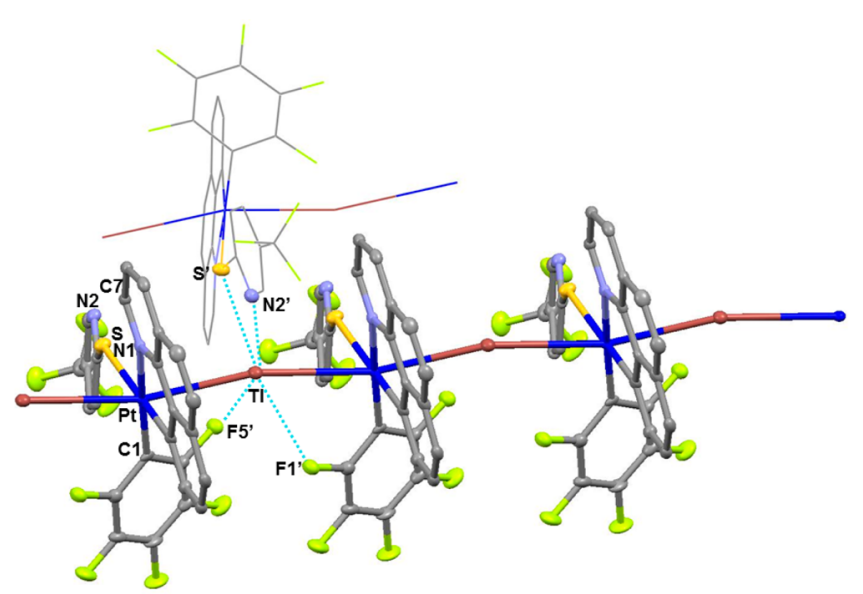

Figure 4. Molecular view of a section of 4 showing the environment of the $\mathrm{Tl}^{\mathrm{I}}$ center. Remarked chain and selected atoms shown as $50 \%$ probability thermal ellipsoids.

Spectra of complexes $1-4$ in $\mathrm{CH}_{2} \mathrm{Cl}_{2}$ solutions are displayed in Figure 5. The similarity of the absorption profiles of all

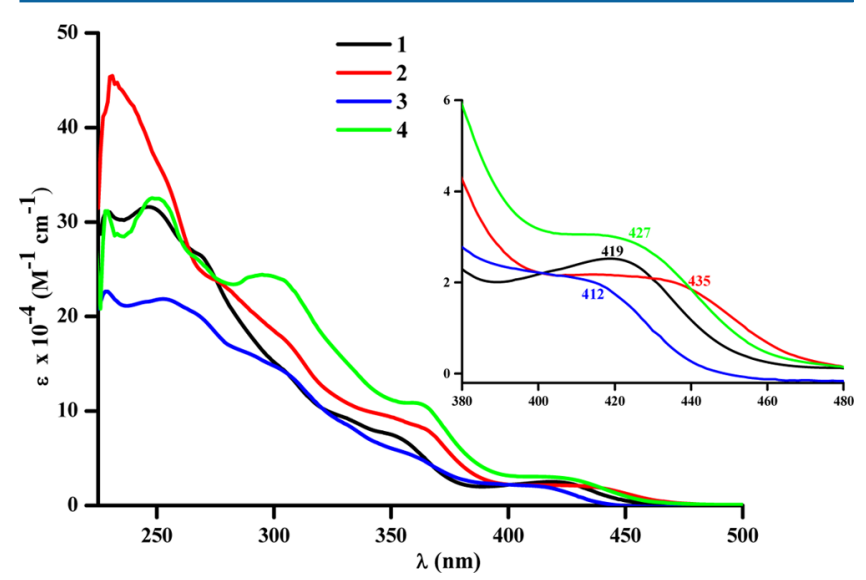

Figure 5. Absorption spectra of $\mathbf{1 - 4}$ in $\mathrm{CH}_{2} \mathrm{Cl}_{2}$ (concentration $=5 \times$ $\left.10^{-5} \mathrm{M}\right)$ at $298 \mathrm{~K}$. Inset: LE region.

complexes indicates that the extended chains 3 and 4 break down in solution, probably as bimetallic fragments $\left[\left\{\mathrm{Pt}\left(\mathrm{C}_{6} \mathrm{~F}_{5}\right)\right.\right.$ $\left.\left.\left(\mathrm{C}^{\wedge} \mathrm{N}\right)\right\} \mathrm{Tl}\left(\mathrm{SpyCF}_{3}-5\right)\right]$ similar to those observed for $\mathbf{1}$ and $\mathbf{2}$ in the solid state. All complexes show intense absorption bands at high energy (HE; range 230-366 $\mathrm{nm}, \varepsilon>5 \times 10^{3} \mathrm{M}^{-1} \mathrm{~cm}^{-1}$ ) and a less intense low-energy (LE) absorption [412-435 $\mathrm{nm}, \varepsilon$ $=(2-3) \times 10^{3} \mathrm{M}^{-1} \mathrm{~cm}^{-1}, \mathrm{CH}_{2} \mathrm{Cl}_{2}$; Figure 5; 409-429 $\mathrm{nm}$ 
Table 2. Photophysical Data for Complexes 1-4 in the Solid State at 298 and $77 \mathrm{~K}$

\begin{tabular}{|c|c|c|c|c|c|c|}
\hline compound & $T / \mathrm{K}$ & $\lambda_{\mathrm{em}} / \mathrm{nm}\left(\lambda_{\mathrm{exc}} / \mathrm{nm}\right)$ & $\tau / \mu \mathrm{s}$ & $\Phi / \%$ & $k_{\mathrm{r}}^{a}$ & $k_{\mathrm{nr}}{ }^{a}$ \\
\hline \multirow[t]{3}{*}[\operatorname{PtTl}(\mathrm{C}_{6}\mathrm{F}_{5})(\mathrm{ppy})(\mathrm{Spy})]{$(\mathbf{1})$} & 298 & $530_{s h}, 610_{\max }(440)$ & $0.3(36 \%), 1.4(64 \%)$ at $610 \mathrm{~nm}$ & 9.9 & $1 \times 10^{5}$ & $9 \times 10^{5}$ \\
\hline & & $625(480-500)$ & $0.03(60 \%), 0.4(40 \%)$ at $530 \mathrm{~nm}$ & & & \\
\hline & 77 & $580(350-480)$ & 13.1 & & & \\
\hline \multirow{3}{*}{$\begin{array}{l}{\left[\mathrm{PtTl}\left(\mathrm{C}_{6} \mathrm{~F}_{5}\right)(\mathrm{bzq})(\mathrm{Spy})\right](\mathbf{2}-\mathbf{o}) \text { (see the }} \\
\text { text) }\end{array}$} & 298 & $620(440-520)$ & $0.7(56 \%), 0.1(44 \%)$ & 6.5 & $1.5 \times 10^{5}$ & $2.2 \times 10^{6}$ \\
\hline & 77 & $530_{\mathrm{sh}}, 620_{\max }(400-440)$ & 11.8 & & & \\
\hline & & $630(480)$ & & & & \\
\hline \multirow[t]{3}{*}{ 2-y (see the text) } & 298 & $507_{\max } 541,560,590(365-440)$ & $0.1(36 \%), 0.5(64 \%)$ at $507 \mathrm{~nm}$ & 2.8 & $7.9 \times 10^{4}$ & $2.7 \times 10^{6}$ \\
\hline & & & 15.1 at $590 \mathrm{~nm}$ & & $2 \times 10^{3}$ & $6.4 \times 10^{4}$ \\
\hline & 77 & $525_{\max }, 580_{\mathrm{sh}}, 625_{\mathrm{sh}}(365-440)$ & $\begin{array}{l}22.2(87 \%), 87.3(23 \%) \text { at } \\
525 \mathrm{~nm}\end{array}$ & & & \\
\hline \multirow[t]{3}{*}{ 2-y-ground } & 298 & $650(440-520)$ & $0.8(52 \%), 0.1(48 \%)$ & 6.6 & $1.4 \times 10^{5}$ & $2.0 \times 10^{6}$ \\
\hline & 77 & $525_{\mathrm{sh}}, 620_{\max }(400-440)$ & 12.1 & & & \\
\hline & & $630(480)$ & & & & \\
\hline \multirow[t]{4}{*}[\operatorname{PtTl}(\mathrm{C}_{6}\mathrm{F}_{5})(\mathrm{ppy})(\mathrm{SpyCF}_{3}-5)]{} & 298 & $515,535,600_{\max }, 615(400-480)$ & $0.05(57 \%), 0.5(43 \%)$ at $535 \mathrm{~nm}$ & 7.2 & $3.0 \times 10^{5}$ & $3.8 \times 10^{6}$ \\
\hline & & $615,640(500)$ & $0.2(27 \%), 1.1(73 \%)$ at $615 \mathrm{~nm}$ & & $8.4 \times 10^{4}$ & $1.1 \times 10^{6}$ \\
\hline & 77 & $515_{\mathrm{sh}}, 590_{\max }(360-440)$ & 9.7 & & & \\
\hline & & $595(480)$ & & & & \\
\hline \multirow[t]{2}{*}{ 3-ground } & 298 & $640(480)$ & $10.1(0.3 \%), 1.1(99.7 \%)$ & 13.5 & $1.2 \times 10^{5}$ & $7.7 \times 10^{5}$ \\
\hline & 77 & $630(480)$ & 9.2 & & & \\
\hline \multirow[t]{2}{*}[\operatorname{PtTl}(\mathrm{C}_{6}\mathrm{F}_{5})(\mathrm{bzq})(\mathrm{SpyCF}_{3}-5)]{$(4)$} & 298 & $540_{\max } 565_{\mathrm{sh}}(365-500)$ & $0.09(63 \%), 0.3(37 \%)$ at $540 \mathrm{~nm}$ & 1.9 & $1.1 \times 10^{5}$ & $5.9 \times 10^{6}$ \\
\hline & 77 & $515,600_{\max }(360-480)$ & 8.2 at $602 \mathrm{~nm}$ & & & \\
\hline \multirow[t]{2}{*}{ 4-ground } & 298 & $630(500)$ & $0.2(37 \%), 0.9(63 \%)$ & 17.5 & $2.7 \times 10^{5}$ & $1.3 \times 10^{6}$ \\
\hline & 77 & $610(480)$ & 10.5 & & & \\
\hline
\end{tabular}

acetone]. According to time-dependent density functional theory (TD-DFT) calculations $\left(\mathrm{CH}_{2} \mathrm{Cl}_{2}\right)$ and to previous assignments, $^{5,22}$ the $\mathrm{HE}$ bands are mainly considered as slightly metal-perturbed intraligand $\left({ }^{1} \mathrm{LC} \pi-\pi^{*}\right)$ transitions, located on the cyclometalated (ppy and bzq) and thiolate (Spy and $\mathrm{SpyCF}_{3}$ ) ligands. The LE bands are ascribed to ligand-toligand charge transfer $\left({ }^{1} \mathrm{~L}^{\prime} \mathrm{LCT}\right.$; Spy or $\left.\mathrm{SpyCF}_{3}-5 \rightarrow \mathrm{C}^{\wedge} \mathrm{N}\right)$ with minor character of intraligand $\left[{ }^{1} \mathrm{LC} ; \pi\left(\mathrm{C}^{\wedge} \mathrm{N}\right) \rightarrow\right.$ $\left.\pi^{*}\left(\mathrm{C}^{\wedge} \mathrm{N}\right)\right]$ and metal-to-ligand charge transfer $\left({ }^{1} \mathrm{MLCT} ; \mathrm{Pt}\right.$ $\left.\rightarrow \mathrm{C}^{\wedge} \mathrm{N}\right)$.

In agreement with this assignment, the LE bands are redshifted upon going from a ppy to bzq cyclometalated ligand (Figure 5), which can be attributed to larger $\pi$ conjugation in the bzq ligand with respect to ppy, which lowers the $\pi^{*}$ energy level, red shifting the transition. ${ }^{7 a, 22 a, e, 23}$ This behavior is in contrast to those previously reported for $\mathrm{Pt}^{\mathrm{II}}-\mathrm{Pb}^{\mathrm{II}}$ trinuclear clusters, in which no noticeable dependence of the cyclometalating ligands was found. ${ }^{15 \mathrm{~b}}$ However, as in those, minor blue shifts from the Spy to $\mathrm{SpyCF}_{3}$ species were detected. ${ }^{15 \mathrm{~b}}$ These LE bands are blue-shifted with increasing solvent polarity [i.e., for 4, $427 \mathrm{~nm}\left(\mathrm{CH}_{2} \mathrm{Cl}_{2}\right)$ and $421 \mathrm{~nm}$ (acetone)], in agreement with their considerable charge-transfer character, typical of negative solvatochromism. ${ }^{22 a, 24}$

Emission Spectra. All complexes display luminescence in the solid state at 298 and $77 \mathrm{~K}$ and in glassy solutions $\left(\mathrm{CH}_{2} \mathrm{Cl}_{2}\right.$ and acetone). None of the derivatives is emissive in solution at 298 K. Their photophysical data are collected in Tables 2 and S6.

Solid State. Under irradiation at room temperature, 1 displays an orange emission with a quantum yield of $9.9 \%$. Photoexcitation in the range $420-440 \mathrm{~nm}$ gives a LE broad featureless emission band centered at $610 \mathrm{~nm}$ with a minor contribution of a HE shoulder at ca. $530 \mathrm{~nm}$ (Figure 6). The main LE band can be selectively obtained by increasing the wavelength of excitation ( $\lambda_{\mathrm{ex}}=480-500 \mathrm{~nm}$ ), exhibiting a small red shift at ca. $15 \mathrm{~nm}$. This band is mainly ascribed to

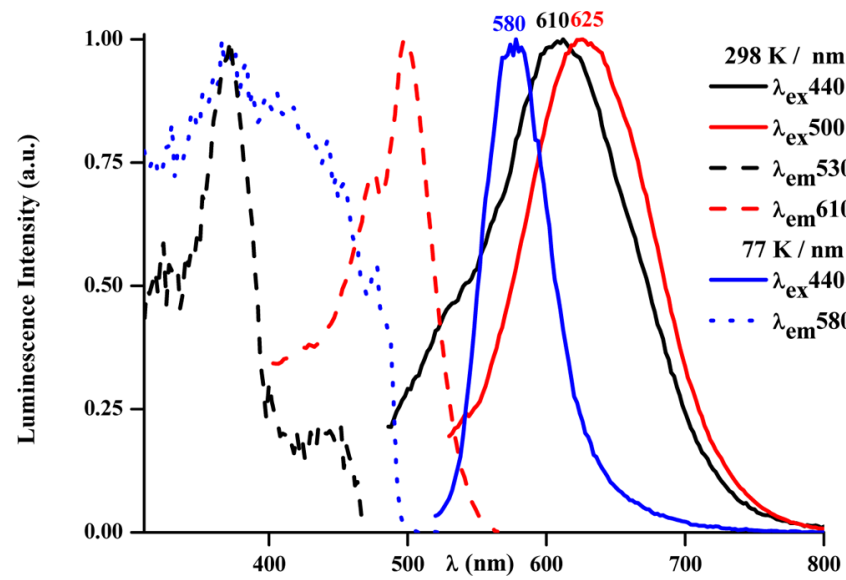

Figure 6. Normalized excitation and emission spectra of $\mathbf{1}$ in the solid state at 298 and $77 \mathrm{~K}$.

excimer $\left({ }^{3} \pi \pi^{*}\right)$ emission, generated by the extensive degree of aggregation through short $\pi \cdots \pi$ intermolecular interactions between the cyclometalating (ppy) ligands, as found in the Xray packing. This behavior has many precedents in cycloplatinated(II) planar complexes having more or less extended $\pi$ systems. On the basis of theoretical calculations (see below), the HE emission can be assigned to monomer emission having ${ }^{3} \mathrm{LC}$ character with some pyridinethiolatoplatinum-to-phenylpyridinyl ${ }^{3}\left[\left(\mathrm{~L}^{\prime}+\mathrm{M}\right) \mathrm{LCT}\right]$ (Spy/Pt $\rightarrow$ ppy) contribution. Probably, the internal conversion between the two emissive states ${ }^{3} \mathrm{LC} /{ }^{3}\left[\left(\mathrm{~L}^{\prime}+\mathrm{M}\right) \mathrm{LCT}\right]$ (high excited state) and ${ }^{3} \pi \pi^{*}$ (low excited state) is relatively slow at $298 \mathrm{~K}$, and both bands are observed. ${ }^{7 a}$ In agreement with this, the excitation spectra monitored in both wavelengths (610 and $530 \mathrm{~nm}$ ) show different profiles and the lifetimes measured in both maxima fit to two components [0.03 (60\%), $0.4(40 \%) \mu \mathrm{s}$, 


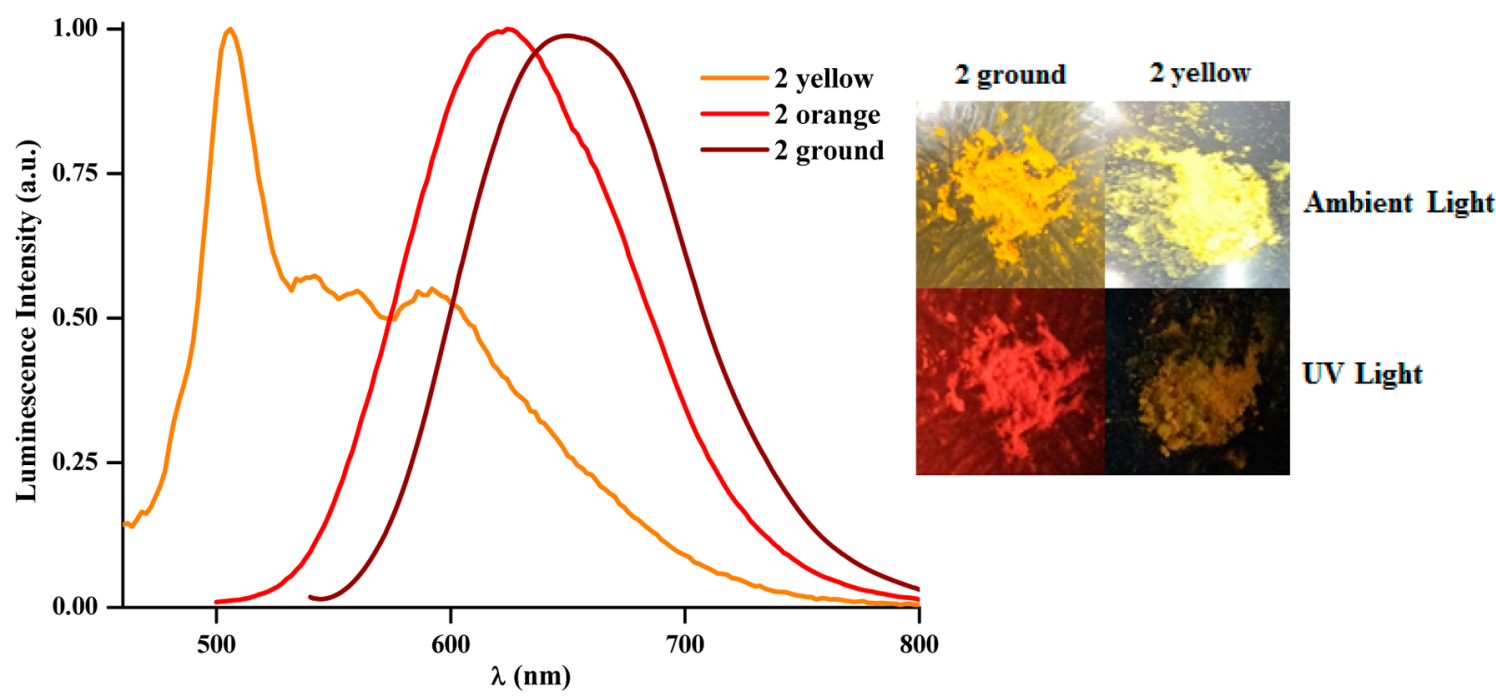

Figure 7. Normalized emission spectra of solid samples of the yellow (2-y), orange (2-o), and brown (2-y-ground) forms at $298 \mathrm{~K}$. Photographs show the color and luminescence changes of $2-y$ after grinding.

$530 \mathrm{~nm}, 0.3(36 \%), 1.4(64 \%) \mu \mathrm{s}, 610 \mathrm{~nm}]$, which indicates that these emissions have some degree of mixed origin (Table 2 ). The possibility that the dual emission observed at room temperature could come from the presence of impurities is ruled out from the ${ }^{1} \mathrm{H}$ NMR spectra of the microcrystalline solid used as the sample. In these types of systems, the existence of site heterogeneity cannot be completely excluded, as is suggested from the dependence of the emission with the excitation wavelengths, probably originating from different conformations of the pyridinethiolatoplatinum fragment around the $\mathrm{Tl}^{\mathrm{I}}$ and/or distinct separations between the $\mathrm{PtTl}$ units. At $77 \mathrm{~K}$, the emission intensity increases remarkably and does not depend on the excitation wavelength. Only the LE band is observed, and both the emission $(580 \mathrm{~nm})$ and excitation spectra are blue-shifted in relation to room temperature (Figure 6). This dependence clearly suggests that the emission is unlikely to be $\mathrm{Pt}-\mathrm{Tl}$ in origin because a red shift upon cooling is generally observed because of a decrease of the distances at lower temperature. ${ }^{5 e, 9 a, 10 b}$ The behavior observed is consistent with the excimer ${ }^{3} \pi \pi^{*}$ character for the emission. Upon cooling, the intramolecular bond distances (including $\mathrm{Pt}-\mathrm{Tl}$ ) are expected to decrease, probably provoking a slight separation in the intermolecular contacts between binuclear units, and this could be the reason for the blue shift in the corresponding emission. The lifetime fits well to one component and is increased up to $13.1 \mu \mathrm{s}$, likely due to the suppression of thermally activated nonradiative processes.

As noted before, the color and luminescence of $\mathbf{2}$ are substantially altered depending on the crystallization conditions. The orange solid 2-o, obtained by fast precipitation, exhibits at $298 \mathrm{~K}$ an intense orange emission at $620 \mathrm{~nm}$ (Figures 7 and S8) with a quantum yield of $\Phi=6.5 \%$. This structureless band is similar to that observed for 1 at $625 \mathrm{~nm}$, and thus it could be assigned to an excimer-like emission associated with $\pi \cdots \pi$ interactions in the ground state. As shown in Figure S8, the energy maximum in 2-o remains essentially unchanged at low temperature $(77 \mathrm{~K})$, although a minor monomer contribution is also detected at $530 \mathrm{~nm}$ upon excitation at $400 \mathrm{~nm}$, probably ${ }^{3} \mathrm{LC} /{ }^{3}\left[\left(\mathrm{~L}^{\prime}+\mathrm{M}\right) \mathrm{LCT}\right](\mathrm{L}=\mathrm{bzq}$; $\left.\mathrm{L}^{\prime}=\mathrm{Spy}\right)$ in nature, as in complex $\mathbf{1}$. The emission decay at 77 $\mathrm{K}(11.8 \mu \mathrm{s})$ is longer than that at $298 \mathrm{~K}[0.7(56 \%)$ and 0.1
(44\%) $\mu \mathrm{s}$ ] because of suppression of the nonradiative deactivation channels and is slightly reduced in relation to $\mathbf{1}$.

Interestingly, the yellow solid (2-y) predominantly displays emission from the monomer $\mathrm{Pt}-\mathrm{Tl}$ unit (Table 2 and Figures 7 and S9). Solid 2-y exhibits at $298 \mathrm{~K}$, upon excitation at $440 \mathrm{~nm}$, a main structured band at $507 \mathrm{~nm}$, with a minor contribution of a broad LE excimer band at $590 \mathrm{~nm}$, which practically overlaps with the tail of the main structured band and decreases by excitation at $\lambda_{\text {exc }}<365 \mathrm{~nm}$. The excitation spectra monitored in both maxima show different profiles, indicative of different origins. The structured band is tentatively ascribed to a mixed ${ }^{3} \mathrm{LC} /{ }^{3}\left[\left(\mathrm{~L}^{\prime}+\mathrm{M}\right) \mathrm{LCT}\right]$ emissive state in the monomer $\mathrm{Pt}-\mathrm{Tl}$ unit, as supported by DFT calculations. The LE band displays a long lifetime, which fits to one component $(15.1 \mu \mathrm{s})$, whereas the $\mathrm{HE}$ band (measured at $507 \mathrm{~nm}$ ) fits to two components and exhibits shorter decays $[0.1(36 \%)$ and $0.5(64 \%) \mu \mathrm{s}]$. Upon cooling to $77 \mathrm{~K}$, the emission profile of this solid displays essentially the structured band slightly red-shifted $\left(\lambda_{\max }=525\right.$ $\mathrm{nm})$, with a biexponential global fit and longer lifetime [22.2 $(87 \%)$ and $87.3(23 \%) \mu \mathrm{s}]$.

We also found that the form 2-y exhibits notable mechanochromic behavior. ${ }^{2 \mathrm{a}, 3 \mathrm{~b}, 5 \mathrm{~d}, \mathrm{e}, 15,25}$ Thus, when the yellow solid 2-y is ground in a mortar, the color gradually turns paleorange and the emission changes to intense orange. After grinding, 2-y-ground shows an absorption spectrum almost coincident with 2-o, extending to $600 \mathrm{~nm}$ (Figure S7b). The emission profile completely changes to an unstructured band with a $143 \mathrm{~nm}$ red shift at the peak maxima and a clear increase in the quantum yield $(\Phi=6.6 \% 2$-y-ground vs $2.8 \% 2$-y; Table 2 and Figures 7 and S10). The new luminescence profile $\left(\lambda_{\mathrm{em}}=\right.$ $650 \mathrm{~nm}$ ) is similar to that observed for the 2-o form but with a remarkable red shift of ca. $30 \mathrm{~nm}$ at $298 \mathrm{~K}$ (Figure 7). As in the as-obtained orange solid $\mathbf{2 - o}$, the luminescence in the ground solid is associated with excimer emission. The observed enhanced quantum yield is not common but has some precedents. $^{26}$ The change in the emission spectrum is associated with structural modifications in the packing, suggesting that the crushed solid probably has close intermolecular $\pi \cdots \pi$-stacking interactions after grinding. ${ }^{15 \mathrm{~b}}$ Upon cooling to $77 \mathrm{~K}$, the ground powder shows, by excitation at $400 \mathrm{~nm}$, the presence of both emissions, a LE band at 620 
$\mathrm{nm}$ and a minor contribution of the $\mathrm{HE}$ band at $525 \mathrm{~nm}$, a pattern clearly similar to that observed in the 2-o form. In a similar way, the lifetime of $\mathbf{2}$-y-ground is very close to that observed for 2-o at both 298 and $77 \mathrm{~K}$ (Table 2). Interestingly, the initial yellow solid (2-y) is recovered upon exposure to $\mathrm{CH}_{2} \mathrm{Cl}_{2}$ or acetone solvent, and this phenomenon is totally reversible for several cycles. To gain knowledge about the mechanism of mechanochromic behavior of complex 2-y, we compared its PXRD pattern before and after mechanical stimulation (Figure 8). The PXRD pattern of the unground

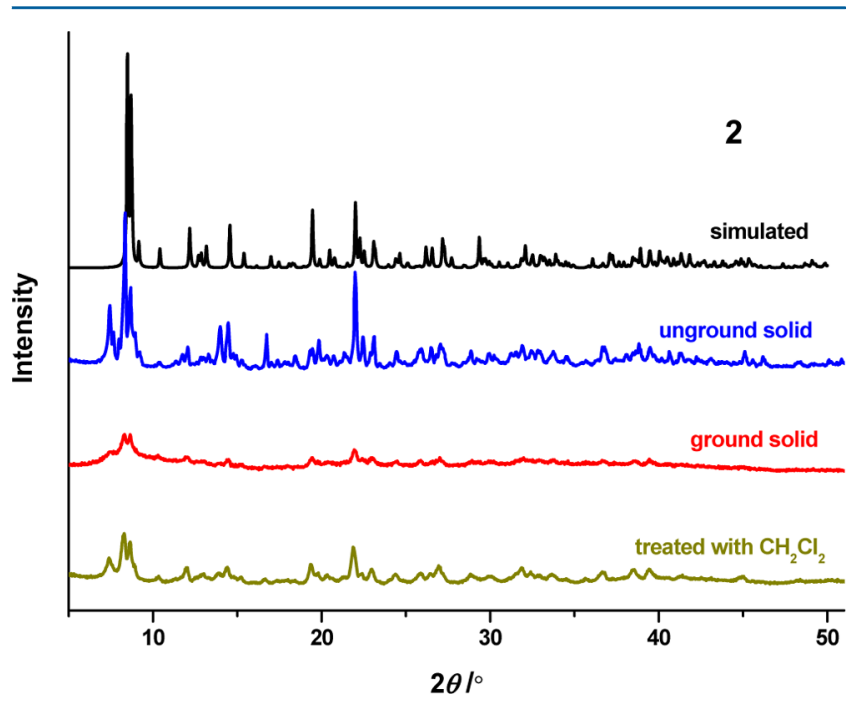

Figure 8. Simulated patterns derived from single crystals (black line) and PXRD patterns of unground solid (blue line), ground solid (red line), and ground solid treated with a drop of $\mathrm{CH}_{2} \mathrm{Cl}_{2}$ (green line) of 2.

yellow sample, 2-y, (blue line) showed clear reflection peaks, in good agreement with the simulated pattern (black line). However, the PXRD pattern of the ground sample showed significant decreased peak intensities and increased peak widths (red-line), indicating that the grinding causes crystal-toamorphous conversion. Upon treatment of the ground sample with a drop of $\mathrm{CH}_{2} \mathrm{Cl}_{2}$, the reflection peaks were partially recovered (green line), indicating partial reversion from the amorphous to crystalline phase.

In complex 3, the presence of two different bands at $298 \mathrm{~K}$ (Table 2 and Figure 9) is also apparent. The emission from monomer at 515 and $535 \mathrm{~nm}$, with a biexponential lifetime, is attributed to a mixed ${ }^{3} \mathrm{LC},{ }^{3} \mathrm{~L}$ LCT $\left(\mathrm{SpyCF}_{3} \rightarrow\right.$ ppy), and ${ }^{3} \mathrm{MLCT}(\mathrm{Pt} \rightarrow$ ppy) excited state, and the LE emission (600 $\mathrm{nm}$ ) is caused by the presence of close $\pi \cdots \pi$ (ppy) interactions between adjacent groups, as suggested by X-ray, which allow the formation of excited ${ }^{3} \pi \pi^{*}$ excimers with slower decays. ${ }^{22 c, 27}$ In agreement to their different origins, the excitation spectra monitored at 535 and $600 \mathrm{~nm}$ are different. Upon a decrease in the temperature $(77 \mathrm{~K})$, the luminescence becomes more intense and changes to orange, with the HE band disappearing and only the unstructured LE band remaining, although slightly blue-shifted (Table 2 and Figure 9), with an increased lifetime (9.7 $\mu \mathrm{s})$.

As shown in Figure 10, the yellow extended [-Pt-Tl $\cdots \mathrm{Pt}-$ $\mathrm{Tl}-$ ] chain 4 displays at $298 \mathrm{~K}$ a yellow phosphorescence emission. In contrast to the dual emission observed in chain 3, in this case, only one emission (540 and $565 \mathrm{~nm}$ ) with a biexponential decay [0.09 (63\%) and $0.3(37 \%) \mu \mathrm{s}$ at $540 \mathrm{~nm}$,

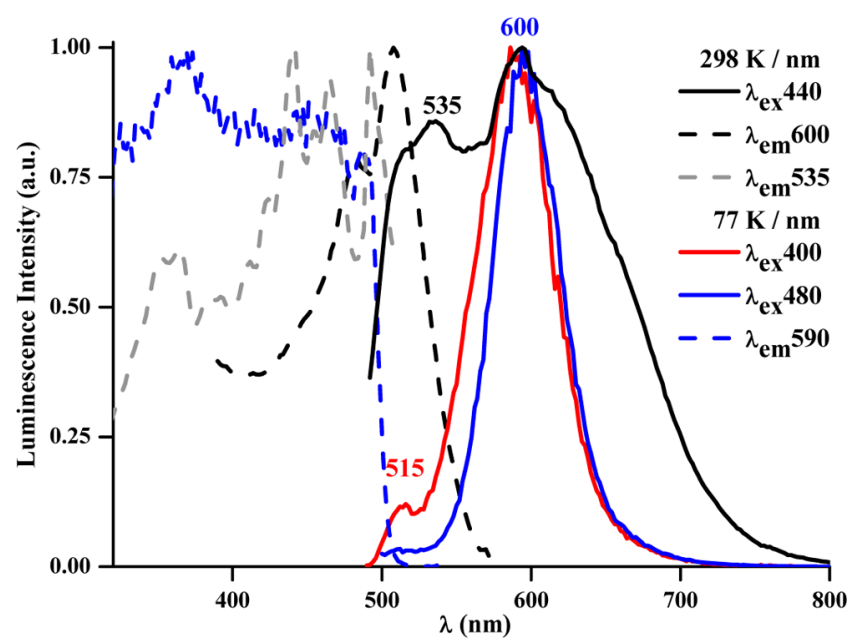

Figure 9. Normalized excitation and emission spectra of 3 in the solid state at 298 and $77 \mathrm{~K}$.

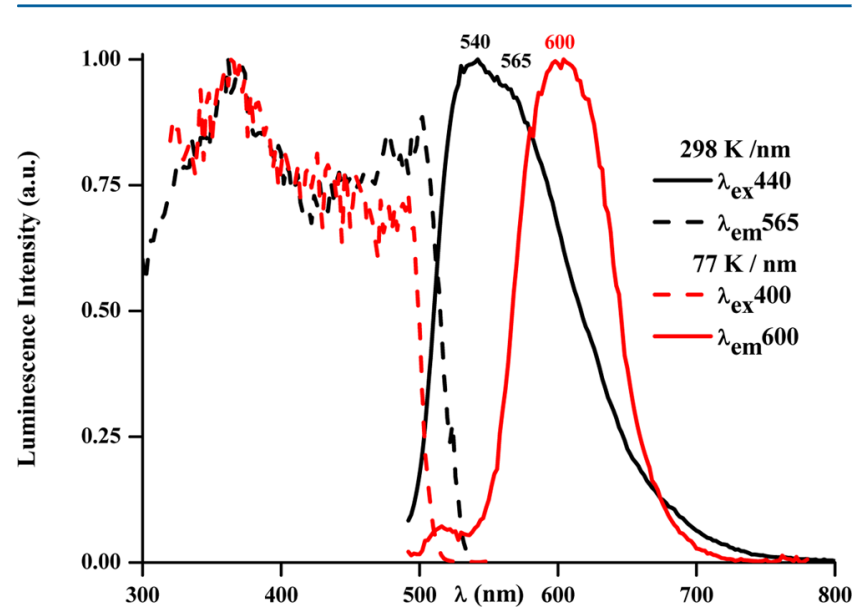

Figure 10. Normalized excitation and emission spectra of 4 in the solid state at 298 and $77 \mathrm{~K}$.

by excitation at the lowest-energy absorption band, is observed. According to calculations (see below), this is the only compound that shows a small contribution of the metal orbitals in the excited state, with the emission being ascribed to interligand $\left(\mathrm{SpyCF}_{3} \rightarrow\right.$ bzq) charge transfer $\left({ }^{3} \mathrm{~L}^{\prime} \mathrm{LCT}\right)$ with minor ${ }^{3} \mathrm{MLCT}$ and ${ }^{3} \mathrm{MM}^{\prime} \mathrm{CT}$ contributions. At $77 \mathrm{~K}$, the emission becomes bright orange. The emission profile retains a minor contribution of the $\mathrm{HE}$ band at $515 \mathrm{~nm}$, and a new and more symmetric band appears at $600 \mathrm{~nm}$. This structureless band with a longer lifetime $(8.2 \mu \mathrm{s})$ probably originates from the occurrence of ${ }^{3} \pi \pi^{*}$-stacking transitions, as illustrated in the crystal-packing structure (Figure S6). An inspection of radiative and nonradiative rate constants $\left(k_{\mathrm{r}}\right.$ and $k_{\mathrm{nr}}$, respectively) shows that the nonradiative rate constants are similar to the $k_{\mathrm{r}}$ values or are 1 order of magnitude higher. The poor quantum yields of 2-y and 4 could be attributable to their higher difference between $k_{\mathrm{r}}$ and $k_{\mathrm{nr}}$.

Both $\mathrm{SpyCF}_{3}$ complexes 3 and $\mathbf{4}$ exhibit a notable mechanochromic behavior with enhancement of photoluminescence. Thus, upon mechanical grinding, their color changes from yellow to orange, whereas the luminescence varies from yellow to bright orange under UV light (Figure S11 for 4). After grinding, crushed solids 3 and 4 display at $298 \mathrm{~K}$ broad absorption bands with long tails to 590-600 nm (Figure S7c,d) 
and unstructured emission bands centered at 640 and $630 \mathrm{~nm}$, respectively (Figures S12 and S13) with a remarkable increase in their quantum yields ( $\Phi$ 13.5\% 3-ground vs $7.2 \% 3$; $17.5 \%$ 4-ground vs $1.9 \%$ 4). The remarkable red shift in the crushed powder suggests a shortening of the $\pi \cdots \pi$ contacts in the chain caused by grinding. ${ }^{7 a, 27}$ At $77 \mathrm{~K}$, only a slight blue shift and an increase of the lifetimes are detectable in relation to $298 \mathrm{~K}$ (Table 2). Interestingly, in both cases, the preliminary yellow solids (ungrounded powder) were recovered upon treatment with some drops of $\mathrm{CH}_{2} \mathrm{Cl}_{2}$ or acetone, being thoroughly reversible for several cycles. ${ }^{5 \mathrm{~d}}$

A comparison of the simulated and PXRD patterns of the ground form shows that complex 3 undergoes, like 2, a remarkable crystal-to-amorphous phase transitions by mechanical stimulation (Figure 11a). Upon treatment of the ground sample with $\mathrm{CH}_{2} \mathrm{Cl}_{2}$, the reflection peaks were restored, which

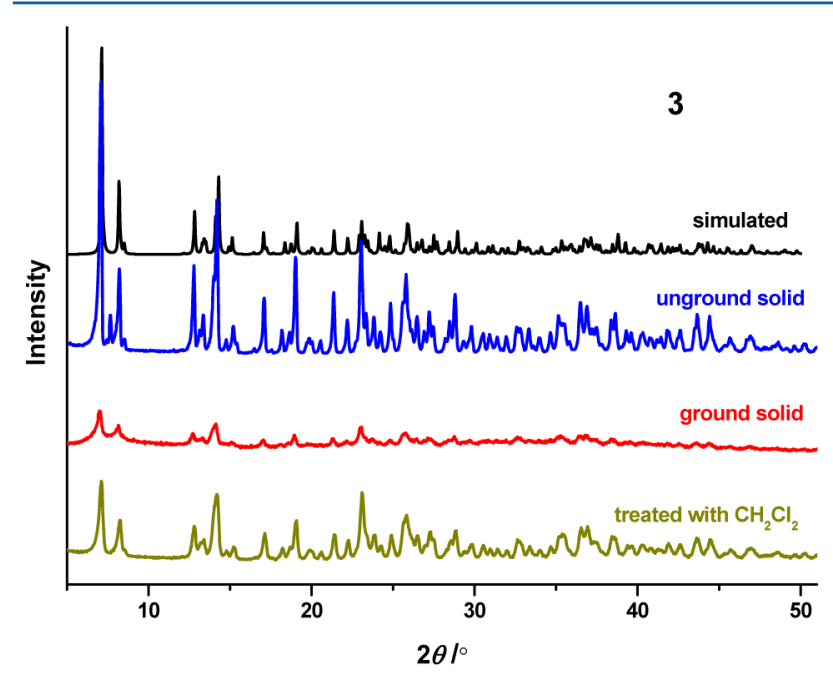

a)

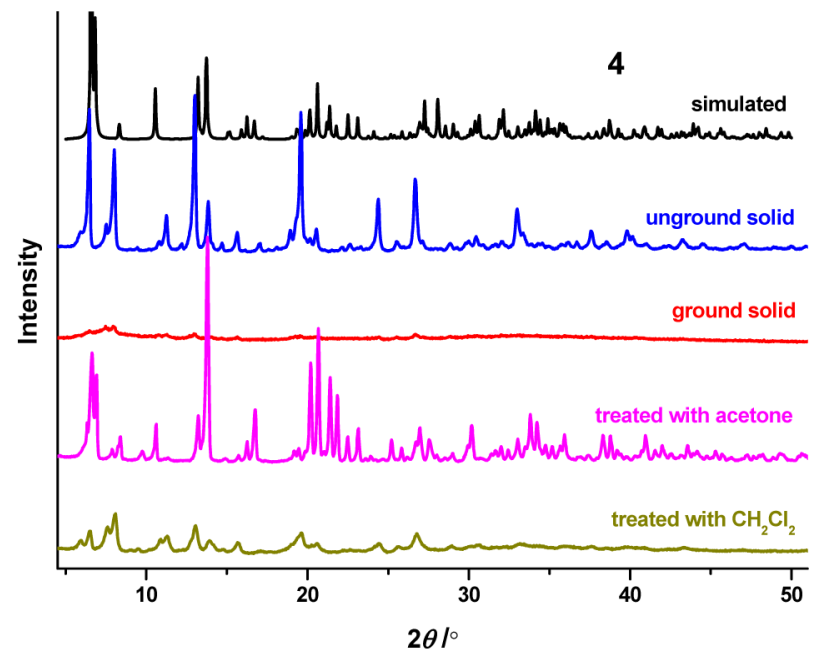

b)

Figure 11. Simulated powder patterns derived from single crystals (black lines) and PXRD patterns of unground solids (blue lines), ground solids (red lines), ground solids treated with a drop of $\mathrm{CH}_{2} \mathrm{Cl}_{2}$ (green lines), and ground solids treated with a drop of acetone (pink lines) of (a) 3 and (b) 4. indicates reversion from the amorphous-to-crystalline phase. In the case of 4 , the PXRD pattern of the unground pristine sample obtained from $\mathrm{CH}_{2} \mathrm{Cl}_{2}$ does not match the simulated pattern of the single crystals obtained from acetone (Figure $11 \mathrm{~b}$, blue and black lines), clearly indicating that the solvent modifies somewhat the arrangement of the molecules in the crystal. The grinding transforms the yellow luminescent microcrystalline powder into a metastable amorphous orange emissive phase (red line), which upon treatment with $\mathrm{CH}_{2} \mathrm{Cl}_{2}$ (green line) matches partially with the unground sample pattern. As expected, treatment of the ground solid with a drop of acetone causes recuperation of a crystalline phase (pink line) with reflection peaks coincident with those simulated by X-ray.

These results suggest that for the three complexes (2-4) stimulation by mechanical grinding transforms the microcrystalline powder into a metastable amorphous phase, in which the $\mathrm{Pt}-\mathrm{Tl}$ aggregates are likely disordered and present stronger $\pi \cdots \pi$ contacts. This leads to a much smaller highest occupied molecular orbital (HOMO)-lowest unoccupied molecular orbital (LUMO) gap, which is responsible for the red shift in the absorption and emission spectra. Upon treatment of the ground sample with a drop of $\mathrm{CH}_{2} \mathrm{Cl}_{2}(2-4)$ or acetone (4), the crystalline phase is rapidly restored.

Solution. Complexes 1-4 are not emissive at $298 \mathrm{~K}$ in $\mathrm{CH}_{2} \mathrm{Cl}_{2}$ or acetone solutions at low $\left(5 \times 10^{-5} \mathrm{M}\right)$ or high $\left(10^{-3}\right.$ $\mathrm{M})$ concentrations, but they are luminescent in these media at $77 \mathrm{~K}$ (Table S6). In glassy solutions, the color and emission are not dependent on the solvent and concentration. They display a yellow color (glassy form) and emit a bright-orange color under UV irradiation. In concentrated solutions of both solvents $\left(10^{-3} \mathrm{M}\right)$, all complexes exhibit a broad featureless intense emission band in the LE region with maxima in the range 615-630 $\mathrm{nm}$ (Figure S14). This unstructured band is clearly similar (in shape and energy) to those in the solid state (Table 2), and therefore it could be attributed to ${ }^{3} \pi \pi^{*}$ excimer emission. In diluted solutions $\left(5 \times 10^{-5} \mathrm{M}\right)$, they show the LE band at position, shape, and intensity similar to those observed in concentrated solutions but in all cases (except for 4) accompanied by a weak structured HE band (Figure S14), which, according to previous assignments, ${ }^{5 e, 7 a, 16,22 a, e, 27}$ could be ascribed to a mixed ${ }^{3} \mathrm{LC} /{ }^{3} \mathrm{MLCT}$ excited state. Both bands are associated with different excitation profiles, suggesting the presence of different emissive manifolds in glass media. ${ }^{15 b, 22 a, 23 a}$

Theoretical Studies. In order to rationalize their optical properties, DFT and TD-DFT calculations have been performed on systems 1-4. The asymmetric units of the crystal structures have been used as starting points for optimization of the complexes. Complex 1 was optimized with three different functionals (B3LYP, CAM-B3LYP, and PBE) and a mixed basis set (6-31g(d)/LanL2DZ), and subsequent TD-DFT calculations were performed using the CPCM $\mathrm{CH}_{2} \mathrm{Cl}_{2}$ solvent model. The simulated absorption spectra (Figure $\mathrm{S} 15 \mathrm{a}-\mathrm{c}$ ) show that B3LYP gives the most accurate results, followed by PBE, while CAM-B3LYP predicts the lowest-energy transition, substantially blue-shifted in comparison with the experimental value. With these results, complexes 1-4 were optimized, followed by TD-DFT using B3LYP and PBE functionals. As can be seen in Figures S15S18, when the computed and experimental spectra are compared, B3LYP gives good results for the Spy complexes 1 and 2, while for the Spy-CF 3 complexes 3 and 4, the LE band is clearly shifted and the shape of the spectrum for 4 does not 


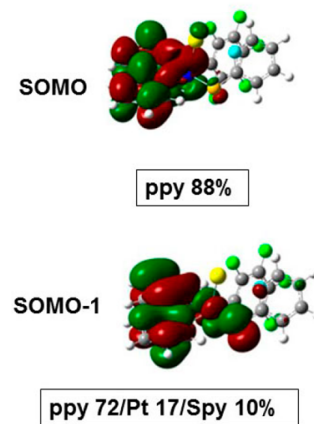

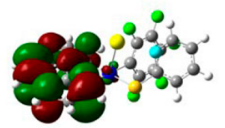

bzq $99 \%$

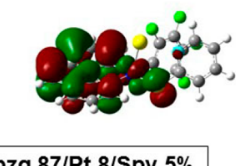

bzq $87 /$ Pt $8 /$ Spy $5 \%$

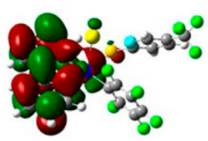

ppy $90 \%$

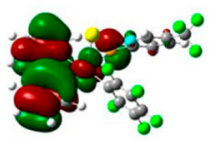

ppy $78 / \mathrm{Pt} 14 / \mathrm{SpyCF}_{3} 7 \%$

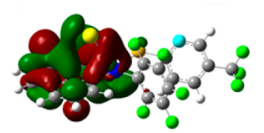

bzq $82 \%$

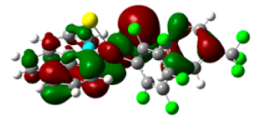

bzq 19/Pt 25/SpyCF 35

Figure 12. SOMO and SOMO-1 of complexes 1-4.

even resemble that of the experimental spectrum. The computed spectra using PBE agree better with the experimental spectra for complexes $\mathbf{3}$ and $\mathbf{4}$, although the LE band is shifted as well, but the shape of the spectra is similar to that of the experimental spectra for all complexes. With this in mind, we decided to use the results obtained using the BPE/6-31g(d)/ LanL2Dz method for comparative purposes.

In contrast to the different geometries observed in the X-ray structures, optimization in the ground state (gas phase) originates in all cases bimetallic PtTl units (Figure S19), with the distances and angles of the optimized structures similar for all complexes (Table S7), which reproduces well the geometrical X-ray parameters for the bimetallic complexes $\mathbf{1}$ and 2. Thus, for $\mathbf{1}$ and 2, calculations show similar $\mathrm{Pt}-\mathrm{Tl}$ distances [2.8848(2) A for $\mathbf{1}$ and 2.8957(2) A for 2 vs calculated 2.91287 $\AA$ for 1 and $2.90700 \AA$ for 2]. However, in the case of 3 and 4, the obtained $\mathrm{S}_{0}$ geometries show systematically shorter $\mathrm{Pt}-\mathrm{Tl}$ and $\mathrm{Tl}-\mathrm{N}$ distances from those seen in the $\mathrm{X}$-ray $[\mathrm{Pt}-\mathrm{Tl}$ $3.0924(2) \AA$ for 3 and 3.1965(2) $\AA$ for 4 vs calculated 2.89171 $\AA$ for 3 and $2.89035 \AA$ for $4 \AA$; Tl-N 2.800(4) $\AA$ for 3 and 2.735(2) $\AA$ for 4 vs calculated $2.62935 \AA$ for 3 and $2.62942 \AA$ for 4]. Selected frontier molecular orbitals are depicted in Figures S20-S23, and their compositions in terms of metals and ligands are collected in Table S8. In all cases, the HOMO is centered on the Spy or $\mathrm{SpyCF}_{3}-5$ group (54-61\%), Pt center (19-20\%), and the cyclometalated $\mathrm{C}^{\wedge} \mathrm{N}$ ligand (16-25\%), while the LUMO is mainly centered on the $\mathrm{C}^{\wedge} \mathrm{N}$ ligand (83$91 \%$ ) with some minor contribution of the metallic centers (4$7 \% \mathrm{Pt}$ and 4-7\% Tl). TD-DFT calculations in $\mathrm{CH}_{2} \mathrm{Cl}_{2}$ (Table S9) show that the lowest-energy transition predicted for all of the complexes is from HOMO to LUMO. Therefore, the LE band can be assigned to transitions from the Spy or $\mathrm{SpyCF}_{3}-5$ fragments to the cyclometalated ligand $\left({ }^{1} \mathrm{~L}^{\prime} \mathrm{LCT}\right)$ with minor contributions of intraligand ${ }^{1} \mathrm{LC}$ and $\mathrm{Pt}$ to cyclometalated ${ }^{1} \operatorname{MLCT}\left(\mathrm{L}=\mathrm{C}^{\wedge} \mathrm{N} ; \mathrm{L}^{\prime}=\mathrm{Spy} ; \mathrm{M}=\mathrm{Pt}\right)$, with the contributions of the transitions to the $\mathrm{Tl}$ center $\left({ }^{1} \mathrm{~L}^{\prime} \mathrm{M}^{\prime} \mathrm{CT}\right.$ and ${ }^{1} \mathrm{MM}^{\prime} \mathrm{CT}$; $\mathrm{L}^{\prime}$ = Spy; $\mathrm{M}=\mathrm{Pt} ; \mathrm{M}^{\prime}=\mathrm{Tl}$ ) being very small.

In order to rationalize the emission properties of these complexes, the first triplet $\left(\mathrm{T}_{1}\right)$ of all complexes was optimized. The computed geometric parameters are similar to those found for the corresponding ground states $S_{0}$ (Table S7 and Figure $\mathrm{S} 19)$, with the main difference being the slightly longer $\mathrm{Pt}-\mathrm{Tl}$ and $\mathrm{Tl}-\mathrm{N}$ distances in the $\mathrm{T}_{1}$ state. The emission energies (537 $\mathrm{nm}, 1 ; 581 \mathrm{~nm}, 2 ; 525 \mathrm{~nm}, 3 ; 570 \mathrm{~nm}, 4)$ were calculated as the energy difference $\left[E_{\mathrm{AE}}=E\left(\mathrm{~T}_{1}\right)-E\left(\mathrm{~S}_{0}\right)\right]$ at the $\mathrm{T}_{1}$-optimized geometries (adiabatic electronic emission). The predicted emission energies agree qualitatively with the $\mathrm{HE}$ emission

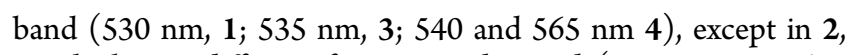
in which two different forms are observed (507 nm, 2-y; 620 $\mathrm{nm}, \mathbf{2 - 0})$. The predicted emission energies show a clear red shift in the bzq derivatives ( 2 and 4 ) in relation to the ppy derivatives ( 1 and 3 ). The spin densities for the $T_{1}$ state for $1-$ 4 are depicted in Figure S24.

For derivatives 1-3, the singly occupied molecular orbitals (SOMOs) are almost identical with the LUMO, being centered in the cyclometalated ligand (Table S10 and Figure 12), whereas the SOMO-1 is located in the triplet state located mainly on the $\mathrm{C}^{\wedge} \mathrm{N}$ ligand (72\% ppy, 1; 87\% bzq, 2; 78\% ppy, 3 ), with minor percentages on the Spy or $\mathrm{SpyCF}_{3}-5$ ligand (10\% 1, 5\% 2, and 7\% 3) and on the Pt (17\% 1, 8\% 2, and 14\% $3)$. Thus, the $\mathrm{HE}$ emission has a pronounced intraligand cyclometalated character ${ }^{3} \mathrm{LC}$ with a minor contribution of pyridinethiolatoplatinum-to-cyclometalated ${ }^{3}\left[\left(\mathrm{~L}^{\prime}+\mathrm{M}\right) \mathrm{LCT}\right]$ nature. In the $\mathrm{SpyCF}_{3}$ derivative 4 , the SOMO is also mainly located on the bzq group (82\%) but has moderate contributions of both metal centers ( $8 \% \mathrm{Pt}$ and $8 \% \mathrm{Tl})$, while the SOMO-1 is similar to the HOMO (55\% $\mathrm{SpyCF}_{3}$, $25 \% \mathrm{Pt}$, and $19 \% \mathrm{bzq}$ ). Consequently, in 4 , the phosphorescence emission is primarily associated with interligand SpyCF$_{3}$-to-bzq charge transfer $\left({ }^{3} \mathrm{~L}^{\prime} \mathrm{LCT}\right)$ with a minor ${ }^{3} \mathrm{MLCT} /{ }^{3} \mathrm{MM}^{\prime} \mathrm{CT}$ contribution.

\section{CONCLUSIONS}

We report the synthesis, structures, and optical properties of four related heterometallic $\mathrm{Pt}-\mathrm{Tl}$ systems. The complexes are accessible by solvent displacement using the platinum solvato chromophores $\left[\mathrm{Pt}\left(\mathrm{C}_{6} \mathrm{~F}_{5}\right)\left(\mathrm{C}^{\wedge} \mathrm{N}\right)(\mathrm{S})\right]$ and the likely polymeric material $[\mathrm{Tl}(\mathrm{Spy})]$ or $\left[\mathrm{Tl}\left(\mathrm{SpyCF}_{3}-5\right)\right]$, generated in situ. The donor characteristics of the pyridinethiolate ancillary ligand and the cyclometalated group have a profound effect on the final structures and luminescence properties. In particular, the $[\mathrm{Tl}(\mathrm{Spy})]$ precursor leads to bimetallic complexes featuring a short $\mathrm{Pt} \rightarrow \mathrm{Tl}$ bond, supported by a typical a $\mu-\kappa \mathrm{S}(\mathrm{Pt}): \kappa \mathrm{N}(\mathrm{Tl})$. However, employing $\left[\mathrm{Tl}\left(\mathrm{SpyCF}_{3}-5\right)\right]$ with a less donating (trifluoromethyl)pyridinethiolate group, the formation of extended networks is observed containing unusual zigzag $-\mathrm{Pt}-\mathrm{Tl} \cdots \mathrm{S}-\mathrm{Pt}-\left[\left\{\mathrm{Pt}\left(\mathrm{C}_{6} \mathrm{~F}_{5}\right)(\mathrm{ppy})\right\} \mathrm{Tl}\left(\mathrm{SpyCF}_{3}-5\right)\right]_{n}$ (3) or more linear $\cdots \mathrm{Pt}-\mathrm{Tl} \cdots \mathrm{Pt}-\mathrm{Tl} \cdots\left[\left\{\mathrm{Pt}\left(\mathrm{C}_{6} \mathrm{~F}_{5}\right)(\mathrm{bzq})\right\} \mathrm{Tl}\left(\mathrm{SpyCF}_{3}-\right.\right.$ $5)]_{n}$ (4) backbones. Crystal-packing analysis reveals the presence of remarkable $\pi \cdots \pi$ stacking in all $1-4$ structures, which influences the emissive properties. Thus, for $\mathbf{1}$, we observe dual emission arising from monomer units [associated with admixture $\left.{ }^{3} \mathrm{LC} /{ }^{3}\left(\mathrm{~L}^{\prime}+\mathrm{M}\right) \mathrm{LCT}\right]$ and aggregated ${ }^{3} \pi \pi$ stacking species. For complex 2, two forms (2-y and 2-o) are 
easily generated, depending on the isolation conditions. 2-y displays mainly the HE monomer yellow emission, whereas 2-o exhibits only an enhanced orange excimer emission (the quantum yield increased by a factor of 2.5 ). The extended chains 3 and 4 show different emission profiles at $298 \mathrm{~K}$. Whereas 3 displays a dual emission from monomer [attributed to admixture ${ }^{3} \mathrm{LC} /{ }^{3}\left(\mathrm{~L}^{\prime}+\mathrm{M}\right) \mathrm{LCT}$, as in the other ppy complex 1] and ${ }^{3} \pi \pi$-stacking species, the chain 4 shows only one emission, assigned to interligand ${ }^{3} \mathrm{~L}^{\prime} \mathrm{LCT}$ with minor ${ }^{3} \mathrm{MLCT}$ character and ${ }^{3} \mathrm{MM}^{\prime} \mathrm{CT}$, as confirmed by theoretical calculations. At $77 \mathrm{~K}$, the ${ }^{3} \pi \pi$-stacking transition is predominant and selectively achieved in all complexes, except in 2-y. Complexes 2-y, 3, and 4 display an interesting and reversible color and luminescent mechanochromic behavior, with an unusual and remarkable increase in the quantum yield of the solids after mechanical stimulation. Analysis of the PXRD changes (before and after mechanical stimulation and after treatment with solvent) confirms the reversible conversion between the crystalline phase of the pristine solids and solvent-treated samples and the amorphous phases of the ground solids. Similar mechanical grinding triggering a crystalline-to-metastable amorphous phase transition has been reported in cycloplatinated systems. ${ }^{25}$ The remarkable red shift in the color and emission observed is attributed to the formation of disordered aggregates with shorter $\pi \cdots \pi$ interactions.

\section{EXPERIMENTAL SECTION}

Materials and Methods. All reactions were carried out under an argon atmosphere using standard Schlenk techniques and solvents from a solvent purification system (Mbraun MB SPS-800). Elemental analyses were carried out with a Carlo Erba EA1110 CHNS/O microanalyzer. Mass spectra were recorded on a Bruker Microflex matrix-assisted laser desorption/ionization time-of-flight (MALDITOF) spectrometer operating in the linear and reflector modes using dithranol as the matrix. IR spectra were recorded on a Nicolet Nexus Fourier transform infrared spectrometer from Nujol mulls between polyethylene sheets. NMR spectra were recorded on a Bruker ARX 300 or ARX 400 spectrometer at $298 \mathrm{~K}$. Chemical shifts are reported in parts per million (ppm) relative to external standards $\left(\mathrm{SiMe}_{4}\right.$ for ${ }^{1} \mathrm{H}$ and ${ }^{13} \mathrm{C}\left\{{ }^{1} \mathrm{H}\right\}$ and $\mathrm{CFCl}_{3}$ for ${ }^{19} \mathrm{~F}$ ), and all coupling constants are given in hertz. UV-vis absorption spectra were carried out in a HewlettPackard 8453 spectrophotometer. Diffuse-reflectance UV-vis (DRUV) data were recorded on a Shimadzu UV-3600 spectrophotometer with a Harrick Praying Mantis accessory and recalculated following the Kubelka-Munk function. Excitation and emission spectra were obtained on a PerkinElmer LS50B or in a Jobin-Yvon Horiba Fluorolog 3-11 Tau-3 spectrofluorimeter. The lifetime measurements were performed in a Jobin-Yvon Horiba Fluorolog spectrofluorimeter operating in the phosphorimeter mode (with an F1-1029 lifetime emission PMT assembly, using a $450 \mathrm{~W}$ xenon lamp) or with a Datastation HUB-B with a nanoLED controller and software DAS6. The nano-LEDs employed for lifetime measurements were of wavelength $450 \mathrm{~nm}$ with pulse lengths of $0.8-1.4 \mathrm{~ns}$. The lifetime data were fitted using the Jobin-Yvon software package. Quantum yields in solid were measured using an F-3018 Integrating Sphere mounted on a Fluorolog 3-11 Tau-3 spectrofluorimeter. PXRD patterns were obtained at room temperature using a Rigaku $\mathrm{D} / \max 2500$ rotatinganode generator with graphite-monochromated $\mathrm{Cu} \mathrm{K} \alpha$ operating at 40 $\mathrm{kV}$ and $80 \mathrm{~mA}$. PXRD patterns were collected between $2 \theta$ of $3^{\circ}$ and $60^{\circ}$ with a $2 \theta$ stepping angle of $0.03^{\circ}$ and an angle dwell of $1 \mathrm{~s}$. Complexes $\left[\mathrm{Pt}\left(\mathrm{C}_{6} \mathrm{~F}_{5}\right)(\mathrm{ppy})(\mathrm{DMSO})\right]^{15 \mathrm{~b}}(\mathrm{~A})$ and $\left[\mathrm{Pt}\left(\mathrm{C}_{6} \mathrm{~F}_{5}\right)(\mathrm{bzq})\right.$ $\left.\left(\mathrm{CH}_{3} \mathrm{COCH}_{3}\right)\right]^{16}(\mathbf{B})$ were prepared as reported in the literature. The $[\mathrm{Tl}(\mathrm{Spy})]$ and $\left[\mathrm{Tl}\left(\mathrm{SpyCF}_{3}-5\right)\right]$ species were freshly prepared by reaction in $\mathrm{CH}_{2} \mathrm{Cl}_{2}(20 \mathrm{~mL})$ of the corresponding HSpy or $\mathrm{HSpyCF}_{3}$ 5 ligand with a suspension of $[\mathrm{Tl}(\mathrm{acac})]$ in a $1: 1$ molar ratio and stirred for $30 \mathrm{~min}$.
Preparation of $\left[\left\{\mathrm{Pt}\left(\mathrm{C}_{6} \mathrm{~F}_{5}\right)(\right.\right.$ ppy) $\left.\} \mathrm{TI}(\mathrm{Spy})\right]$ (1). To a yellow suspension of $[\mathrm{Tl}(\mathrm{Spy})](0.336 \mathrm{mmol})$, prepared in situ from $[\mathrm{Tl}(\mathrm{acac})](0.103$ g) and HSpy $(0.037 \mathrm{~g})$ in $20 \mathrm{~mL}$ of $\mathrm{CH}_{2} \mathrm{Cl}_{2}$, was added $\mathbf{A}(0.2 \mathrm{~g}, 0.336$ $\mathrm{mmol})$, and the mixture was further stirred for $40 \mathrm{~min}$. The deepyellow solution formed was concentrated to small volume $(\sim 2 \mathrm{~mL})$ under vacuum, and $n$-hexane $(10 \mathrm{~mL})$ was added to give $\mathbf{1}$ as a yellow solid, which was filtered and washed with $n$-hexane $(5 \mathrm{~mL}, 0.244 \mathrm{~g}$, $87 \%$ yield). Anal. Calcd for $\mathrm{C}_{22} \mathrm{H}_{12} \mathrm{~F}_{5} \mathrm{~N}_{2} \mathrm{PtSTl}$ : C, 31.77; $\mathrm{H}, 1.46 ; \mathrm{N}$, 3.37; S, 3.85. Found: C, 32.10; H, 1.72; N, 2.97; S, 4.07. MALDITOF $(+): m / z 1034\left([\mathrm{M}+\mathrm{Tl}]^{+} ; 38\right), 940\left([\mathrm{M}+(\mathrm{SpyH})]^{+} ; 86\right), 831$ $\left([\mathrm{M}]^{+} ; 43\right) . \mathrm{IR}\left(\mathrm{cm}^{-1}\right): \nu\left(\mathrm{C}_{6} \mathrm{~F}_{5}\right.$ Xsens $) 798$ (vs). ${ }^{1} \mathrm{H}$ NMR $(\delta, 400.17$ $\left.\mathrm{MHz}, \mathrm{CD}_{3} \mathrm{COCD}_{3}\right): 9.25\left(\mathrm{~d}, J_{\mathrm{H}-\mathrm{H}}=5.6,{ }^{3} J_{\mathrm{Pt}-\mathrm{H}}=22.7, \mathrm{H}_{\mathrm{ppy}}^{2}\right), 8.21(\mathrm{~d}$, $\left.J_{\mathrm{H}-\mathrm{H}}=5.0, \mathrm{H}_{\text {Spy }}^{6}\right), 8.10-8.08\left(\mathrm{~m}, \mathrm{H}_{\mathrm{ppy}}^{4}, \mathrm{H}_{\mathrm{ppy}}^{5}\right), 7.78\left(\mathrm{dd}, J_{\mathrm{H}-\mathrm{H}}=7.7\right.$, $\left.J_{\mathrm{H}-\mathrm{H}}=1.0, \mathrm{H}_{\mathrm{ppy}}^{6}\right), 7.37-7.28\left(\mathrm{~m}, \mathrm{H}_{\text {Spy }}^{3}, \mathrm{H}^{4}{ }_{\mathrm{Spy}}, \mathrm{H}^{3}{ }_{\mathrm{ppy}}\right), 7.08\left(\mathrm{td}, J_{\mathrm{H}-\mathrm{H}}=\right.$ 7.7, $\left.J_{\mathrm{H}-\mathrm{H}}=1.0, \mathrm{H}_{\mathrm{ppy}}^{7}\right), 7.01-6.94\left(\mathrm{~m}, \mathrm{H}_{\mathrm{Spy}}^{5}, \mathrm{H}_{\mathrm{ppy}}^{8}\right), 6.90\left(\mathrm{~d}, J_{\mathrm{H}-\mathrm{H}}=\right.$ $\left.7.5,{ }^{3} J_{\mathrm{Pt}-\mathrm{H}}=58.2, \mathrm{H}_{\mathrm{ppy}}^{9}\right) .{ }^{19} \mathrm{~F} \mathrm{NMR}\left(\delta, 282.4 \mathrm{MHz}, \mathrm{CD}_{3} \mathrm{COCD}_{3}\right)$ : $-117.6\left(\mathrm{dm},{ }^{3} J_{\mathrm{Pt}-\mathrm{F}_{o}}=415,2 \mathrm{~F}^{o}\right),-166.1\left(\mathrm{~m}, 1 \mathrm{~F}^{p}, 2 \mathrm{~F}^{m}\right) .{ }^{13} \mathrm{C}\left\{{ }^{1} \mathrm{H}\right\} \mathrm{NMR}$ $\left(\delta, 100.6 \mathrm{MHz}, \mathrm{CD}_{3} \mathrm{COCD}_{3}\right): 169.0\left(\mathrm{~s}^{2} J_{\mathrm{Pt}-\mathrm{C}}=63, \mathrm{C}_{\mathrm{Spy}}^{2}\right), 167.8(\mathrm{~s}$, $\left.{ }^{2} J_{\mathrm{Pt}-\mathrm{C}}=82, \mathrm{C}^{12}{ }_{\mathrm{ppy}}\right), 151.1\left(\mathrm{~s}, \mathrm{C}_{\mathrm{ppy}}^{2}\right), 150.5\left(\mathrm{~s}, \mathrm{C}^{11}{ }_{\mathrm{ppy}}\right), 148.1\left(\mathrm{~s}, \mathrm{C}_{\mathrm{Spy}}^{6}\right)$, $147.9\left(\mathrm{~s}, \mathrm{C}_{\mathrm{ppy}}^{10}\right), 141.5\left(\mathrm{~s}, \mathrm{C}_{\mathrm{ppy}}^{4}\right), 138.1\left(\mathrm{~s},{ }^{2} \mathrm{~J}_{\mathrm{Pt}-\mathrm{C}}=97, \mathrm{C}_{\mathrm{ppy}}^{9}\right), 137.4$ $\left(\mathrm{s}, \mathrm{C}_{\mathrm{Spy}}^{4}\right), 132.1\left(\mathrm{~s},{ }^{3} \mathrm{~J}_{\mathrm{Pt}-\mathrm{C}}=41, \mathrm{C}_{\mathrm{Spy}}^{3}\right), 132.0\left(\mathrm{~s},{ }^{3} J_{\mathrm{Pt}-\mathrm{C}}=65, \mathrm{C}_{\mathrm{ppy}}^{8}\right)$, $126.0\left(\mathrm{~s}^{3} \mathrm{~J}_{\mathrm{Pt}-\mathrm{C}}=37, \mathrm{C}_{\mathrm{ppy}}^{6}\right), 125.6\left(\mathrm{~s}, \mathrm{C}_{\mathrm{ppy}}^{7}\right), 125.0\left(\mathrm{~s},{ }^{3} J_{\mathrm{Pt}-\mathrm{C}}=32\right.$, $\left.\mathrm{C}_{\mathrm{ppy}}^{3}\right), 121.3\left(\mathrm{~s},{ }^{3} \mathrm{~J}_{\mathrm{Pt}-\mathrm{C}}=36, \mathrm{C}_{\mathrm{ppy}}^{5}\right), 119.8\left(\mathrm{~s}, \mathrm{C}_{\mathrm{Spy}}^{5}\right)$.

Preparation of $\left[\left\{\mathrm{Pt}\left(\mathrm{C}_{6} F_{5}\right)(\right.\right.$ bzq $\left.\left.)\right\} T I(S p y)\right]$ (2). This compound was obtained as an orange solid $(0.359 \mathrm{~g}, 91 \%$ yield $)$ following a procedure similar to that described for $\mathbf{1}$, using starting precursors $[\mathrm{Tl}(\mathrm{Spy})](0.5$ $\mathrm{mmol})$ and $\mathbf{B}(0.3 \mathrm{~g}, 0.5 \mathrm{mmol})$. Anal. Calcd for $\mathrm{C}_{24} \mathrm{H}_{12} \mathrm{~F}_{5} \mathrm{~N}_{2} \mathrm{PtSTl}$ : C, 34.04; H, 1.41; N, 3.27; S, 3.74. Found: C, 34.54; H, 1.56; N, 3.07; S, 3.86. MALDI-TOF(+): $m / z 1600\left(\left[\mathrm{Pt}_{2} \mathrm{Tl}_{2}\left(\mathrm{C}_{6} \mathrm{~F}_{5}\right)_{2}(\text { bzq })_{2}(\mathrm{Spy})\right]^{+} ; 27\right)$, $964\left([\mathrm{M}+(\mathrm{SpyH})]^{+} ; 20\right), 1059\left([\mathrm{M}+\mathrm{Tl}]^{+} ; 40\right), 855\left([\mathrm{M}]^{+} ; 100\right) . \mathrm{IR}$ $\left(\mathrm{cm}^{-1}\right): \nu\left(\mathrm{C}_{6} \mathrm{~F}_{5}\right.$ Xsens $) 800$ (vs). ${ }^{1} \mathrm{H}$ NMR $(\delta, 400.17 \mathrm{MHz}$, $\left.\mathrm{CD}_{3} \mathrm{COCD}_{3}\right): 9.45\left(\mathrm{dd}, J_{\mathrm{H}-\mathrm{H}}=5.3, J_{\mathrm{H}-\mathrm{H}}=1.3,{ }^{3} J_{\mathrm{Pt}-\mathrm{H}}=23.3\right.$, $\left.\mathrm{H}^{2}{ }_{\text {bzq }}\right), 8.64\left(\mathrm{dd}, J_{\mathrm{H}-\mathrm{H}}=8.1, J_{\mathrm{H}-\mathrm{H}}=1.3, \mathrm{H}^{4}\right.$ bzq $), 8.19\left(\mathrm{dd}, J_{\mathrm{H}-\mathrm{H}}=5.3\right.$, $\left.J_{\mathrm{H}-\mathrm{H}}=0.8, \mathrm{H}_{\text {Spy }}^{6}\right), 7.90\left(\mathrm{~d}, J_{\mathrm{H}-\mathrm{H}}=8.8, \mathrm{H}^{5 / 6}{ }_{\text {bzq }}\right), 7.79\left(\mathrm{~d}, J_{\mathrm{H}-\mathrm{H}}=8.8\right.$, $\left.\mathrm{H}^{5 / 6}{ }_{\text {bzq }}\right), 7.72\left(\mathrm{dd}, J_{\mathrm{H}-\mathrm{H}}=8.1, J_{\mathrm{H}-\mathrm{H}}=5.3, \mathrm{H}_{\text {bzq }}^{3}\right), 7.66\left(\mathrm{~d}, J_{\mathrm{H}-\mathrm{H}}=7.9\right.$, $\left.\mathrm{H}_{\text {bzq }}^{7}\right), 7.48\left(\mathrm{~d}, J_{\mathrm{H}-\mathrm{H}}=8.1, \mathrm{H}_{\mathrm{Spy}}^{3}\right), 7.42-7.38\left(\mathrm{~m}, \mathrm{H}_{\text {Spy }}^{4}, \mathrm{H}_{\text {bzq }}^{8}\right), 7.12$ $\left(\mathrm{d}, J_{\mathrm{H}-\mathrm{H}}=7.1,{ }^{3} \mathrm{~J}_{\mathrm{Pt}-\mathrm{H}}=56.3, \mathrm{H}_{\mathrm{bzq}}^{9}\right), 7.00\left(\mathrm{~m}, \mathrm{H}_{\mathrm{Spy}}^{5}\right) \cdot{ }^{9} \mathrm{~F}$ NMR $(\delta$, $\left.282.4 \mathrm{MHz}, \mathrm{CD}_{3} \mathrm{COCD}_{3}\right):-117.5\left(\mathrm{dm},{ }^{3} J_{\mathrm{Pt}-\mathrm{F}_{o}}=422,2 \mathrm{~F}^{o}\right),-166.1$ $\left(\mathrm{m}, 1 \mathrm{~F}^{p}, 2 \mathrm{~F}^{m}\right) .{ }^{13} \mathrm{C}\left\{{ }^{1} \mathrm{H}\right\} \operatorname{NMR}\left(\delta, 100.6 \mathrm{MHz}, \mathrm{CD}_{3} \mathrm{COCD}_{3}\right): 170.1(\mathrm{~s}$, $\left.\mathrm{C}_{\text {Spy }}^{2}\right), 156.3\left(\mathrm{~s},{ }^{2} J_{\mathrm{Pt}-\mathrm{C}}=68, \mathrm{C}^{12}\right.$ bzq $), 152.4\left(\mathrm{~s}, \mathrm{C}^{2}{ }_{\text {bzq }}\right), 148.4\left(\mathrm{~s}, \mathrm{C}^{14}\right.$ bzq $)$, $148.3\left(\mathrm{~s}, \mathrm{C}^{6}{ }_{\mathrm{Spy}}\right), 142.1\left(\mathrm{~s}, \mathrm{C}^{10}{ }_{\mathrm{bzq}}\right), 138.3\left(\mathrm{~s}, \mathrm{C}_{\mathrm{bzq}}^{4}\right), 134.0\left(\mathrm{~s}, \mathrm{C}_{\mathrm{bzq}}^{11}\right)$, $133.4\left(\mathrm{~s},{ }^{2} J_{\mathrm{Pt}-\mathrm{C}}=100, \mathrm{C}_{\mathrm{bzq}}^{9}\right), 130.3\left(\mathrm{~s}, \mathrm{C}_{\mathrm{Spy}}^{4}\right), 129.7\left(\mathrm{~s},{ }^{3} J_{\mathrm{Pt}-\mathrm{C}}=65\right.$, $\left.\mathrm{C}_{\mathrm{bzq}}^{8}\right), 129.4\left(\mathrm{~s}, \mathrm{C}^{5 / 6}{ }_{\mathrm{bzq}}\right), 127.3\left(\mathrm{~s},{ }^{3} \mathrm{~J}_{\mathrm{Pt}-\mathrm{C}}=36, \mathrm{C}_{\mathrm{Spy}}^{3}\right), 123.5\left(\mathrm{~s}, \mathrm{C}^{13}{ }_{\mathrm{bzq}}\right)$, $122.2\left(\mathrm{~s}, \mathrm{C}^{5 / 6}{ }_{\mathrm{bzq}}\right), 122.0\left(\mathrm{~s},{ }^{3} J_{\mathrm{Pt}-\mathrm{C}}=21, \mathrm{C}_{\mathrm{bzq}}^{3}\right), 121.0\left(\mathrm{~s}, \mathrm{C}_{\mathrm{bzq}}^{7}\right), 117.6$ $\left(\mathrm{q},{ }^{2} J_{\mathrm{C}-\mathrm{F}}=32, \mathrm{C}_{\text {Spy }}^{5}\right)$.

Preparation of $\left[\left\{P t\left(C_{6} F_{5}\right)(\text { ppy })\right\} T I\left(\operatorname{SpyCF}_{3}-5\right)\right]_{n}$ (3). To a suspension of $\left[\mathrm{Tl}\left(\mathrm{SpyCF}_{3}-5\right)\right](0.336 \mathrm{mmol})$, prepared in situ from $[\mathrm{Tl}(\mathrm{acac})]$ $(0.103 \mathrm{~g}, 0.336 \mathrm{mmol})$ and $\mathrm{HSpyCF}_{3}-5(0.060 \mathrm{~g}, 0.336 \mathrm{mmol})$ in $\mathrm{CH}_{2} \mathrm{Cl}_{2}(20 \mathrm{~mL})$, was added $\mathbf{A}(0.2 \mathrm{~g}, 0.336 \mathrm{mmol})$, and the mixture was further stirred for $40 \mathrm{~min}$. The deep-yellow solution formed was concentrated to a small volume $(\sim 2 \mathrm{~mL})$ under vacuum, and $n$-hexane $(10 \mathrm{~mL})$ was added to give 3 as a yellow solid, which was filtered and washed with $n$-hexane $(5 \mathrm{~mL}, 0.268 \mathrm{~g}, 89 \%$ yield). Anal. Calcd for $\mathrm{C}_{23} \mathrm{H}_{11} \mathrm{~F}_{8} \mathrm{~N}_{2} \mathrm{PtSTl}$ : C, 30.74; $\mathrm{H}, 1.23 ; \mathrm{N}, 3.12 ; \mathrm{S}$, 3.57. Found: $\mathrm{C}$, 30.86; H, 1.30; N, 2.76; S, 3.72. MALDI-TOF $(+): \mathrm{m} / z 1620$ $\left(\left[\mathrm{Pt}_{2} \mathrm{Tl}_{2}\left(\mathrm{C}_{6} \mathrm{~F}_{5}\right)_{2}(\mathrm{ppy})_{2}\left(\mathrm{SpyCF}_{3}\right)\right]^{+}, 25\right), 1103\left([\mathrm{M}+\mathrm{Tl}]^{+}, 100\right), 898$ $\left([\mathrm{M}]^{+}, 20\right) . \mathrm{IR}\left(\mathrm{cm}^{-1}\right): \nu\left(\mathrm{C}_{6} \mathrm{~F}_{5}\right.$ Xsens $) 798(\mathrm{vs}) .{ }^{1} \mathrm{H}$ NMR $(\delta, 400.17$ $\left.\mathrm{MHz}, \mathrm{CD}_{3} \mathrm{COCD}_{3}\right): 9.22\left(\mathrm{~d}, J_{\mathrm{H}-\mathrm{H}}=5.6,{ }^{3} J_{\mathrm{Pt}-\mathrm{H}}=22.3, \mathrm{H}_{\mathrm{ppy}}^{2}\right), 8.55(\mathrm{~s}$, $\left.\mathrm{H}_{\mathrm{SpyCF}_{3}}^{6}\right), 8.12-8.06\left(\mathrm{~m}, \mathrm{H}_{\mathrm{ppy}}^{4}, \mathrm{H}_{\mathrm{ppy}}^{5}\right), 7.80\left(\mathrm{dd}, J_{\mathrm{H}-\mathrm{H}}=7.6, J_{\mathrm{H}-\mathrm{H}}=\right.$ $\left.1.0, \mathrm{H}_{\mathrm{ppy}}^{6}\right), 7.58\left(\mathrm{~d}, J_{\mathrm{H}-\mathrm{H}}=8.6, \mathrm{H}_{\mathrm{SpyCF}_{3}}^{3}\right), 7.52\left(\mathrm{dd}, J_{\mathrm{H}-\mathrm{H}}=8.6, J_{\mathrm{H}-\mathrm{H}}=\right.$ $\left.2.1, \mathrm{H}_{\mathrm{SpyCF}_{3}}\right), 7.34\left(\mathrm{~m}, \mathrm{H}_{\mathrm{ppy}}^{3}\right), 7.10\left(\mathrm{td}, J_{\mathrm{H}-\mathrm{H}}=7.5, J_{\mathrm{H}-\mathrm{H}}=1.2, \mathrm{H}_{\mathrm{ppy}}^{7}\right)$, $7.03\left(\mathrm{td}, J_{\mathrm{H}-\mathrm{H}}=7.5, J_{\mathrm{H}-\mathrm{H}}=1.2, \mathrm{H}_{\mathrm{ppy}}^{8}\right), 6.94\left(\mathrm{~d}, J_{\mathrm{H}-\mathrm{H}}=7.5,{ }^{3} J_{\mathrm{Pt}-\mathrm{H}}=\right.$ $\left.57.3, \mathrm{H}_{\mathrm{ppy}}^{9}\right){ }^{19} \mathrm{~F} \mathrm{NMR}\left(\delta, 282.4 \mathrm{MHz}, \mathrm{CD}_{3} \mathrm{COCD}_{3}\right):-61.7(\mathrm{~s}, 3 \mathrm{~F}$ $\left.\mathrm{SpyCF}_{3}\right),-117.4\left(\mathrm{dm},{ }^{3} \mathrm{~J}_{\mathrm{Pt}-\mathrm{F}_{\mathrm{o}}}=401,2 \mathrm{~F}^{o}\right),-165.5\left(\mathrm{t}, 1 \mathrm{~F}^{p}\right),-166.0(\mathrm{~m}$, $\left.2 \mathrm{~F}^{m}\right) .{ }^{13} \mathrm{C}\left\{{ }^{1} \mathrm{H}\right\} \operatorname{NMR}\left(\delta, 100.6 \mathrm{MHz}, \mathrm{CD}_{3} \mathrm{COCD}_{3}\right): 175.0\left(\mathrm{~s},{ }^{2} J_{\mathrm{Pt}-\mathrm{C}}=\right.$ $\left.69, \mathrm{C}_{\mathrm{PpyCF}_{3}}^{2}\right), 168.7\left(\mathrm{~s},{ }^{2} J_{\mathrm{Pt}-\mathrm{C}}=74, \mathrm{C}_{\mathrm{ppy}}^{12}\right), 151.6\left(\mathrm{~s}, \mathrm{C}_{\mathrm{ppy}}^{2}\right), 149.9(\mathrm{~s}$, $\left.\mathrm{C}^{11}{ }_{\mathrm{ppy}}\right), 147.8\left(\mathrm{~s}, \mathrm{C}^{10}{ }_{\mathrm{ppy}}\right), 145.8\left(\mathrm{~s}, \mathrm{C}^{6}{ }_{\mathrm{SpyCF}_{3}}\right), 141.5\left(\mathrm{~s}, \mathrm{C}_{\mathrm{ppy}}^{4}\right), 138.2(\mathrm{~s}$, 
$\left.{ }^{2} J_{\mathrm{Pt}-\mathrm{C}}=95, \mathrm{C}_{\mathrm{ppy}}^{9}\right), 133.1\left(\mathrm{~s}, \mathrm{C}_{\mathrm{SpyCF}_{3}}^{4}\right), 132.1\left(\mathrm{~s},{ }^{3} J_{\mathrm{Pt}-\mathrm{C}}=65, \mathrm{C}_{\mathrm{ppy}}^{8}\right)$, $131.2\left(\mathrm{~s},{ }^{3} J_{\mathrm{Pt}-\mathrm{C}}=38, \mathrm{C}^{3} \mathrm{SpyCF}_{3}\right), 126.1\left(\mathrm{~s},{ }^{3} \mathrm{~J}_{\mathrm{Pt}-\mathrm{C}}=38, \mathrm{C}_{\mathrm{ppy}}^{6}\right), 126.0(\mathrm{~s}$, $\left.\mathrm{C}_{\mathrm{ppy}}^{7}\right), 125.1\left(\mathrm{~s},{ }^{3} \mathrm{~J}_{\mathrm{Pt}-\mathrm{C}}=34, \mathrm{C}_{\mathrm{ppy}}^{3}\right), 121.4\left(\mathrm{~s},{ }^{3} \mathrm{~J}_{\mathrm{Pt}-\mathrm{C}}=28, \mathrm{C}_{\mathrm{ppy}}^{5}\right), 120.9$ (s, $\mathrm{C}_{\mathrm{SpyCF}_{3}}^{5}$ ).

Preparation of $\left[\left\{\mathrm{Pt}\left(\mathrm{C}_{6} F_{5}\right)(\mathrm{bzq})\right\} \mathrm{TI}\left(\mathrm{Spy}_{\mathrm{C}} \mathrm{F}_{3}-5\right)\right]_{n}$ (4). Compound 4 was isolated as a yellow solid $(0.247 \mathrm{~g}, 80 \%$ yield) following a procedure similar to that described for 3 , using starting precursors $\left[\mathrm{Tl}\left(\mathrm{SpyCF}_{3}-5\right)\right](0.334 \mathrm{mmol})$ and $\mathbf{B}(0.2 \mathrm{~g}, 0.334 \mathrm{mmol})$. Anal. Calcd for $\mathrm{C}_{25} \mathrm{H}_{11} \mathrm{~F}_{8} \mathrm{~N}_{2} \mathrm{PtSTl}$ : C, 32.54; H, 1.20; N, 3.04; S, 3.47. Found: C, 32.51; H, 1.27; N, 2.96; S, 3.89. MALDI-TOF $(+): m / z 1668$ $\left(\left[\mathrm{Pt}_{2} \mathrm{Tl}_{2}\left(\mathrm{C}_{6} \mathrm{~F}_{5}\right)_{2}(\mathrm{bzq})_{2}\left(\mathrm{SpyCF}_{3}\right)\right]^{+} ; 30\right), 1127\left([\mathrm{M}+\mathrm{Tl}]^{+} ; 100\right), 923$ $\left([\mathrm{M}]^{+} ; 10\right), 757\left(\left[\mathrm{M}-\left(\mathrm{C}_{6} \mathrm{~F}_{5}\right)\right]^{+} ; 42\right) . \mathrm{IR}\left(\mathrm{cm}^{-1}\right): \nu\left(\mathrm{C}_{6} \mathrm{~F}_{5}\right.$ Xsens $) 801$ (vs). ${ }^{1} \mathrm{H} \operatorname{NMR}\left(\delta, 400.17 \mathrm{MHz}, \mathrm{CD}_{3} \mathrm{COCD}_{3}\right): 9.42\left(\mathrm{dd}, J_{\mathrm{H}-\mathrm{H}}=5.3\right.$, $\left.J_{\mathrm{H}-\mathrm{H}}=1.2,{ }^{3} J_{\mathrm{Pt}-\mathrm{H}}=23.0, \mathrm{H}_{\mathrm{bzq}}^{2}\right), 8.63\left(\mathrm{dd}, J_{\mathrm{H}-\mathrm{H}}=8.1, J_{\mathrm{H}-\mathrm{H}}=1.2\right.$, $\left.\mathrm{H}_{\text {bzq }}^{4}\right), 8.53\left(\mathrm{~s}, \mathrm{H}_{\mathrm{SpyCF}_{3}}^{6}\right), 7.91\left(\mathrm{~d}, J_{\mathrm{H}-\mathrm{H}}=8.8, \mathrm{H}^{5 / 6}{ }_{\text {bzq }}\right), 7.80\left(\mathrm{~d}, J_{\mathrm{H}-\mathrm{H}}=\right.$ $8.8, \mathrm{H}^{5 / 6}$ bzq $), 7.73-7.64\left(\mathrm{~m}, \mathrm{H}_{\text {SpyCF }_{3}}^{3} \mathrm{H}_{\text {bzq }}^{3}, \mathrm{H}_{\text {bzq }}^{7}\right), 7.55\left(\mathrm{dd}, J_{\mathrm{H}-\mathrm{H}}=\right.$ $\left.8.7, J_{\mathrm{H}-\mathrm{H}}=2.2, \mathrm{H}_{\mathrm{SpyCF}_{3}}^{4}\right), 7.44\left(\mathrm{t}, J_{\mathrm{H}-\mathrm{H}}=7.3, \mathrm{H}_{\mathrm{bzq}}^{8}\right), 7.18\left(\mathrm{~d}, J_{\mathrm{H}-\mathrm{H}}=\right.$ $\left.7.3,{ }^{3} J_{\mathrm{Pt}-\mathrm{H}}=55.5, \mathrm{H}_{\mathrm{bzq}}^{9}\right) .{ }^{19} \mathrm{~F} \mathrm{NMR}\left(\delta, 282.4 \mathrm{MHz}, \mathrm{CD}_{3} \mathrm{COCD}_{3}\right)$ : $-65.1\left(\mathrm{~s}, 3 \mathrm{~F}_{\mathrm{SpyCF}_{3}}\right),-117.6\left(\mathrm{~m},{ }^{3} J_{\mathrm{Pt}-\mathrm{F}_{o}}=413,2 \mathrm{~F}^{o}\right),-165.5\left(\mathrm{t}, 1 \mathrm{~F}^{p}\right)$, $-165.9\left(\mathrm{~m}, 2 \mathrm{~F}^{m}\right) .{ }^{13} \mathrm{C}\left\{{ }^{1} \mathrm{H}\right\} \operatorname{NMR}\left(\delta, 100.6 \mathrm{MHz}, \mathrm{CD}_{3} \mathrm{COCD}_{3}\right): 175.1$ $\left(\mathrm{s},{ }^{2} J_{\mathrm{Pt}-\mathrm{C}}=64, \mathrm{C}_{\mathrm{SpyCF}_{3}}^{2}\right), 158.0\left(\mathrm{~s},{ }^{2} J_{\mathrm{Pt}-\mathrm{C}}=70, \mathrm{C}^{12}{ }_{\mathrm{bzq}}\right), 151.0(\mathrm{~s}, 1 \mathrm{C}$, $\left.\mathrm{C}_{\text {bzq }}^{2}\right), 148.2\left(\mathrm{~s}, \mathrm{C}^{14}{ }_{\mathrm{bzq}}\right), 145.8\left(\mathrm{~s}, \mathrm{br}, \mathrm{C}_{\mathrm{SpyCF}_{3}}^{6}\right), 143.9\left(\mathrm{~s}, \mathrm{C}^{10}{ }_{\mathrm{bzq}}\right), 140.3$ $\left(\mathrm{s}, \mathrm{C}_{\mathrm{bzq}}^{4}\right), 136.0\left(\mathrm{~s}, \mathrm{C}^{11}{ }_{\mathrm{bzq}}\right), 135.6\left(\mathrm{~s},{ }^{2} \mathrm{~J}_{\mathrm{Pt}-\mathrm{C}}=99, \mathrm{C}_{\mathrm{bzq}}^{9}\right), 133.0(\mathrm{~m}$, $\mathrm{C}_{\mathrm{SpyCF}_{3}}^{4}, 131.6\left(\mathrm{~s},{ }^{3} J_{\mathrm{Pt}-\mathrm{C}}=70, \mathrm{C}_{\mathrm{bzq}}^{8}\right), 131.3\left(\mathrm{~s}, \mathrm{C}_{\mathrm{bzq}}^{5 / 6}\right), 131.1(\mathrm{~s}$, $\left.{ }^{3} J_{\mathrm{Pt}-\mathrm{C}}=34, \mathrm{C}_{\mathrm{Spy}^{3} \mathrm{CF}_{3}}\right), 129.2\left(\mathrm{~s},{ }^{2} \mathrm{JPt}_{\mathrm{Pt}-\mathrm{C}}=23, \mathrm{C}^{13}{ }_{\mathrm{bzq}}\right), 125.5\left(\mathrm{~s}, \mathrm{C}^{5 / 6}{ }_{\mathrm{bzq}}\right)$, $124.3\left(\mathrm{~s}, \mathrm{C}_{\mathrm{bzq}}^{7}\right), 124.2\left(\mathrm{~s},{ }^{3} J_{\mathrm{Pt}-\mathrm{C}}=22, \mathrm{C}_{\mathrm{bzq}}^{3}\right), 120.9\left(\mathrm{q},{ }^{2} J_{\mathrm{C}-\mathrm{F}}=34\right.$, $\left.\mathrm{C}^{5} \mathrm{SpyCF}_{3}\right)$.

X-ray Crystallography. Details of the X-ray analyses are summarized in Table S11. Yellow (1, 2-y, 3, and 4) crystals were obtained by the slow diffusion of $n$-hexane into solutions of the complexes in acetone $\left(1,-30{ }^{\circ} \mathrm{C} ; 3\right.$ and 4 , room temperature) or $\mathrm{CH}_{2} \mathrm{Cl}_{2}\left(2-\mathrm{y},-30{ }^{\circ} \mathrm{C}\right)$. The radiation used in all cases was graphitemonochromated Mo $\mathrm{K} \alpha(\lambda=0.71073 \AA)$. For 1 and 4 , X-ray intensity data were collected on an Oxford Diffraction Xcalibur diffractometer, and the diffraction frames were integrated and corrected from absorption by using the CrysAlisRED program. ${ }^{28}$ For 2 and 3, X-ray intensity data were collected with a Nonius $\kappa \mathrm{CCD}$ area-detector diffractometer, and the diffraction frames were integrated and corrected from absorption by the DENZO and SCALEPACK suite of programs. ${ }^{29}$ The structures were solved by Patterson and Fourier methods using SHELXS ${ }^{30}$ (1 and 4) or DIRDIF2008 ${ }^{31}$ (3) or by intrinsic phasing using SHELXT ${ }^{32}(2-y)$ and refined by full-matrix least squares on $F^{2}$ with SHELXL. ${ }^{33}$ All non-H atoms were assigned anisotropic displacement parameters. All of the $\mathrm{H}$ atoms were constrained to idealized geometries fixing isotropic displacement parameters 1.2 times the $U_{\text {iso }}$ value of their attached C atom. Finally, the structures of 1 and $\mathbf{4}$ show some residual peaks greater than $1 \mathrm{e}$ $\mathrm{A}^{-3}$ in the vicinity of the $\mathrm{Pt}$ and $\mathrm{Tl}$ atoms but with no chemical meaning.

Computational Details for Theoretical Calculations. DFT and TD-DFT calculations were undertaken on the complexes 1-4 by using the Gaussian $03^{34}$ and Gaussian $09^{35}$ packages. Geometry optimizations of the singlet ground $\left(\mathrm{S}_{0}\right)$ and first triplet excited $\left(\mathrm{T}_{1}\right)$ states, and subsequent TD-DFT calculations were carried out by using the $\mathrm{B}^{2} \mathrm{LYP}^{36}$ and $\mathrm{PBEO}^{37}$ (25\% exchange and $75 \%$ correlation weighting) functionals. The basis set used for the metal centers ( $\mathrm{Pt}$ and $\mathrm{Tl})$ was the LanL2DZ effective core potential ${ }^{38}$ and $6-31+\mathrm{G}(\mathrm{d}, \mathrm{p})$ for the ligand atoms. The solvent effect of dichloromethane in the TDDFT calculations was taken into consideration by the polarizable continuum model (PCM). ${ }^{39}$ The calculated emission maxima were estimated from the differences between the ground state and triplet excited state energies at the optimized triplet state geometry.

\section{ASSOCIATED CONTENT}

\section{Supporting Information}

The Supporting Information is available free of charge on the ACS Publications website at DOI: 10.1021/acs.inorgchem.6b00699.

Tables and figures giving crystallographic, photophysical, and theoretical data for compounds prepared in this paper (PDF)

X-ray crystallographic data in CIF format (CIF)

Cartesian coordinates (XYZ)

\section{AUTHOR INFORMATION}

\section{Corresponding Authors}

*E-mail: elena.lalinde@unirioja.es.

*E-mail: teresa.moreno@unirioja.es.

\section{Notes}

The authors declare no competing financial interest.

\section{ACKNOWLEDGMENTS}

This work was supported by the Spanish MINECO (Project CTQ2013-45518-P). A.M. thanks the Spanish MINECO (Project CTQ2015-67461-P) for financial support. H.R.S. is grateful to the Institute for Advanced Studies in Basic Sciences Research Council and the Iran National Science Foundation (Grant 93026027). The authors thank CESGA for computer support and Servicio General de Apoyo a la Investigación-SAI (Universidad de Zaragoza) for technical support in the PXRD experiments.

\section{REFERENCES}

(1) (a) Balch, A. L. Metal-metal bonds and clusters in chemistry; Plenum: New York, 1990. (b) Sculfort, S.; Braunstein, P. Chem. Soc. Rev. 2011, 40, 2741. (c) Katz, M. J.; Sakai, K.; Leznoff, D. B. Chem. Soc. Rev. 2008, 37, 1884. (d) Moret, M. E. Top. Organomet. Chem. 2011, 35, 157. (e) Bauer, J.; Braunschweig, H.; Dewhurst, R. D. Chem. Rev. 2012, 112, 4329. (f) Metal Clusters in Chemistry; Braunstein, P., Oro, L. A., Raithby, P. R., Eds.; Wiley-VCH: New York, 1999. (g) Schmidbaur, H.; Schier, A. Chem. Soc. Rev. 2012, 41, 370. (h) Anderson, B. M.; Hurst, S. K. Eur. J. Inorg. Chem. 2009, 2009, 3041. (i) Doerrer, L. H. Dalton Trans. 2010, 39, 3543.

(2) (a) Yam, V. W.-W.; Au, V. K.-M.; Leung, S. Y.-L. Chem. Rev. 2015, 115, 7589. (b) Díez, A.; Lalinde, E.; Moreno, M. T. Coord. Chem. Rev. 2011, 255, 2426. (c) Che, C.-M.; Lai, S.-W. Gold Chemistry; Wiley-VCH Verlag GmbH \& Co. KGaA: Weinheim, Germany, 2009; p 249. (d) López-de-Luzuriaga, J. M. Modern Supramolecular Gold Chemistry; Wiley-VCH Verlag GmbH \& Co. KGaA: Weinheim, Germany, 2009; p 347. (e) Wong, K. M.-C.; Yam, V. W.-W. Acc. Chem. Res. 2011, 44, 424. (f) Chen, Z. N.; Zhao, N.; Fan, Y.; Ni, J. Coord. Chem. Rev. 2009, 253, 1. (g) He, X.; Yam, V. W. W. Coord. Chem. Rev. 2011, 255, 2111. (h) Yam, V. W.-W.; Cheng, E. C.-C. Chem. Soc. Rev. 2008, 37, 1806. (i) Chen, Z.-N.; Fan, Y.; Ni, J. Dalton Trans. 2008, 573.

(3) (a) Zhang, X.; Li, B.; Chen, Z. H.; Chen, Z. N. J. Mater. Chem. 2012, 22, 11427. (b) Wenger, O. S. Chem. Rev. 2013, 113, 3686. (c) Zhao, Q.; Li, F.; Huang, C. Chem. Soc. Rev. 2010, 39, 3007. (d) Kobayashi, A.; Kato, M. Eur. J. Inorg. Chem. 2014, 2014, 4469. (e) Lima, J. C.; Rodríguez, L. Chem. Soc. Rev. 2011, 40, 5442. (f) Yam, V. W.-W.; Wong, K. M.-C. Chem. Commun. 2011, 47, 11579. (g) Omary, M. A.; Mohamed, A. A.; Rawashdeh-Omary, M. A.; Fackler, J. P., Jr Coord. Chem. Rev. 2005, 249, 1372. (h) Balch, A. L. Angew. Chem., Int. Ed. 2009, 48, 2641.

(4) (a) Berenguer, J. R.; Lalinde, E.; Moreno, M. T. Coord. Chem. Rev. 2010, 254, 832. (b) Yam, V. W. W.; Lo, K. K. W.; Wong, K. M. C. J. Organomet. Chem. 1999, 578, 3. (c) Wong, K. M.-C.; Hui, C.-K.; Yu, K.-L.; Yam, V. W.-W. Coord. Chem. Rev. 2002, 229, 123. (d) Forniés, 
J.; Martin, A. Metal Clusters in Chemistry; Wiley-VCH Verlag GmbH: Berlin, 2008; p 417. (e) Forniés, J.; Ibáñez, S.; Martín, A.; Sanz, M.; Berenguer, J. R.; Lalinde, E.; Torroba, J. Organometallics 2006, 25, 4331. (f) Forniés, J.; Ibáñez, S.; Martín, A.; Gil, B.; Lalinde, E.; Moreno, M. T. Organometallics 2004, 23, 3963. (g) Yamaguchi, T.; Yamazaki, F.; Ito, T. J. Am. Chem. Soc. 2001, 123, 743. (h) Yamaguchi, T.; Yamazaki, F.; Ito, T. J. Am. Chem. Soc. 1999, 121, 7405. (i) Falvello, L. R.; Forniés, J.; Lalinde, E.; Menjón, B.; García Monforte, M. A.; Moreno, M. T.; Tomás, M. Chem. Commun. 2007, 3838. (j) Forniés, J.; Sicilia, V.; Casas, J. M.; Martín, A.; López, J. A.; Larraz, C.; Borja, P.; Ovejero, C. Dalton Trans. 2011, 40, 2898. (k) Forniés, J.; Ibáñez, S.; Lalinde, E.; Martín, A.; Moreno, M. T.; Tsipis, A. C. Dalton Trans. 2012, 41, 3439. (1) Fuertes, S.; Woodall, C. H.; Raithby, P. R.; Sicilia, V. Organometallics 2012, 31, 4228. (m) Martín, A.; Belío, Ú.; Fuertes, S.; Sicilia, V. Eur. J. Inorg. Chem. 2013, 2231. (n) Baya, M.; Belío, Ú.; Forniés, J.; Martín, A.; Perálvarez, M.; Sicilia, V. Inorg. Chim. Acta 2015, 424, 136.

(5) (a) Ara, I.; Falvello, L. R.; Forniés, J.; Gómez-Cordón, J.; Lalinde, E.; Merino, R. I.; Usón, I. J. Organomet. Chem. 2002, 663, 284. (b) Casas, J. M.; Forniés, J.; Martín, A.; Orera, V. M.; Orpen, A. G.; Rueda, A. Inorg. Chem. 1995, 34, 6514. (c) Berenguer, J. R.; Díez, A.; Fernández, J.; Forniés, J.; García, A.; Gil, B.; Lalinde, E.; Moreno, M. T. Inorg. Chem. 2008, 47, 7703. (d) Berenguer, J. R.; Fernández, J.; Gil, B.; Lalinde, E.; Sánchez, S. Chem. - Eur. J. 2014, 20, 2574. (e) Forniés, J.; Giménez, N.; Ibáñez, S.; Lalinde, E.; Martín, A.; Moreno, M. T. Inorg. Chem. 2015, 54, 4351.

(6) Maliarik, M.; Nagle, J. K.; Ilyukhin, A.; Murashova, E.; Mink, J.; Skripkin, M.; Glaser, J.; Kovacs, M.; Horváth, A. Inorg. Chem. 2007, 46, 4642 .

(7) (a) Forniés, J.; Fuertes, S.; Martín, A.; Sicilia, V.; Gil, B.; Lalinde, E. Dalton Trans. 2009, 2224. (b) Forniés, J.; Fortuño, C.; Ibáñez, S.; Martín, A. Inorg. Chem. 2008, 47, 5978. (c) Usón, R; Forniés, J.; Tomás, M.; Garde, R.; Merino, R. I. Inorg. Chem. 1997, 36, 1383. (d) Balch, A. L.; Rowley, S. P. J. Am. Chem. Soc. 1990, 112, 6139. (e) Oberbeckmann-Winter, N.; Braunstein, P.; Welter, R. Organometallics 2004, 23, 6311. (f) Barnett, B. R.; Moore, C. E.; Chandrasekaran, P.; Sproules, S.; Rheingold, A. L.; DeBeer, S.; Figueroa, J. S. Chem. Sci. 2015, 6, 7169.

(8) (a) Nagle, J. K.; Balch, A. L.; Olmstead, M. M. J. Am. Chem. Soc. 1988, 110, 319. (b) Charmant, J. P. H.; Forniés, J.; Gómez, J.; Lalinde, E.; Merino, R. I.; Moreno, M. T.; Orpen, A. G. Organometallics 2003, 22, 652. (c) Berenguer, J. R.; Fernández, J.; Lalinde, E.; Sánchez, S. Chem. Commun. 2012, 48, 6384.

(9) (a) Falvello, L. R.; Forniés, J.; Garde, R.; García, A.; Lalinde, E.; Moreno, M. T.; Steiner, A.; Tomás, M.; Usón, I. Inorg. Chem. 2006, 45, 2543. (b) Song, H. B.; Zhang, Z. Z.; Hui, H.; Che, C. M.; Mak, M. C. W. Inorg. Chem. 2002, 41, 3146. (c) Chen, W.; Liu, F.; Xu, D. X.; Matsumoto, K.; Kishi, S.; Kato, M. Inorg. Chem. 2006, 45, 5552. (d) Renn, O.; Lippert, B.; Mutikainen, I. Inorg. Chim. Acta 1993, 208, 219.

(10) (a) Díez, A.; Forniés, J.; Gómez, J.; Lalinde, E.; Martín, A.; Moreno, M. T.; Sánchez, S. Dalton Trans. 2007, 3653. (b) Forniés, J.; García, A.; Lalinde, E.; Moreno, M. T. Inorg. Chem. 2008, 47, 3651. (c) Díez, Á.; Fernández, J.; Lalinde, E.; Moreno, M. T.; Sánchez, S. Inorg. Chem. 2010, 49, 11606. (d) Stork, J. R.; Olmstead, M. M.; Balch, A. L. J. Am. Chem. Soc. 2005, 127, 6512. (e) Stork, J. R.; Olmstead, M. M.; Fettinger, J. C.; Balch, A. L. Inorg. Chem. 2006, 45, 849.

(11) (a) Belío, Ú.; Fuertes, S.; Martín, A. Inorg. Chem. 2013, 52, 5627. (b) Belío, U.; Fuertes, S.; Martín, A. Dalton Trans. 2014, 43, 10828 .

(12) (a) Berenguer, J. R.; Forniés, J.; Gil, B.; Lalinde, E. Chem. - Eur. J. 2006, 12, 785. (b) Berenguer, J. R.; Forniés, J.; Gómez, J.; Lalinde, E.; Moreno, M. T. Organometallics 2001, 20, 4847.

(13) (a) Berenguer, J. R.; Forniés, J.; Gil, B.; Lalinde, E. Chem. - Eur. J. 2006, 12, 785. (b) Wu, G.; Wang, D. J. Cluster Sci. 2007, 18, 406. (14) (a) Shimoni-Livny, L.; Glusker, J. P.; Bock, C. W. Inorg. Chem. 1998, 37, 1853. (b) Davidovich, R. L.; Stavila, V.; Marinin, D. V.; Voit, E. I.; Whitmire, K. H. Coord. Chem. Rev. 2009, 253, 1316. (c) Davidovich, R. L.; Stavila, V.; Whitmire, K. H. Coord. Chem. Rev.
2010, 254, 2193. (d) Gourlaouen, C.; Gérard, H.; Piquemal, J.-P.; Parisel, O. Chem. - Eur. J. 2008, 14, 2730. (e) Greer, B. J.; Michaelis, V. K.; Katz, M. J.; Leznoff, D. B.; Schreckenbach, G.; Kroeker, S. Chem. Eur. J. 2011, 17, 3609.

(15) (a) Berenguer, J. R.; Lalinde, E.; Martín, A.; Moreno, M. T.; Ruiz, S.; Sánchez, S.; Shahsavari, H. R. Chem. Commun. 2013, 49, 5067. (b) Berenguer, J. R.; Lalinde, E.; Martín, A.; Moreno, M. T.; Ruiz, S.; Sánchez, S.; Shahsavari, H. R. Inorg. Chem. 2014, 53, 8770.

(16) Berenguer, J. R.; Lalinde, E.; Moreno, M. T.; Sánchez, S.; Torroba, J. Inorg. Chem. 2012, 51, 11665.

(17) (a) Jamali, S.; Ghazfar, R.; Lalinde, E.; Jamshidi, Z.; Samouei, H.; Shahsavari, H. R.; Moreno, M. T.; Escudero-Adan, E.; BenetBuchholz, J.; Milic, D. Dalton Trans. 2014, 43, 1105. (b) Jamali, S.; Ashtiani, M. M.; Jamshidi, Z.; Lalinde, E.; Moreno, M. T.; Samouei, H.; Escudero-Adán, E.; Benet-Buchholz, J. Inorg. Chem. 2013, 52, 10729.

(18) Ara, I.; Berenguer, J. R.; Forniés, J.; Gómez, J.; Lalinde, E.; Merino, R. I. Inorg. Chem. 1997, 36, 6461.

(19) Raper, E. S. Coord. Chem. Rev. 1997, 165, 475.

(20) (a) Akhbari, K.; Morsali, A. Coord. Chem. Rev. 2010, 254, 1977. (b) Akrivos, P. D. Coord. Chem. Rev. 2001, 213, 181.

(21) Bondi, A. J. Phys. Chem. 1964, 68, 441.

(22) (a) Berenguer, J. R.; Díez, A.; Lalinde, E.; Moreno, M. T.; Ruiz, S.; Sánchez, S. Organometallics 2011, 30, 5776. (b) Díez, A.; Forniés, J.; Fuertes, S.; Larraz, C.; López, J. A.; Lalinde, E.; Martín, A.; Moreno, M. T.; Sicilia, V. Organometallics 2009, 28, 1705. (c) Díez, A.; Forniés, J.; Larraz, C.; Lalinde, E.; López, J. A.; Martin, A.; Moreno, M. T.; Sicilia, V. Inorg. Chem. 2010, 49, 3239. (d) Bossi, A.; Rausch, A. F.; Leitl, M. J.; Czerwieniec, R.; Whited, M. T.; Djurovich, P. I.; Yersin, H.; Thompson, M. E. Inorg. Chem. 2013, 52, 12403. (e) Brooks, J.; Babayan, Y.; Lamansky, S.; Djurovich, P. I.; Tsyba, I.; Bau, R.; Thompson, M. E. Inorg. Chem. 2002, 41, 3055.

(23) (a) Jamshidi, M.; Nabavizadeh, S. M.; Shahsavari, H. R.; Rashidi, M. RSC Adv. 2015, 5, 57581. (b) Sicilia, V.; Forniés, J.; Fuertes, S.; Martín, A. Inorg. Chem. 2012, 51, 10581.

(24) (a) Zhong, F.; Karatay, A.; Zhao, L.; Zhao, J.; He, C.; Zhang, C.; Yaglioglu, H. G.; Elmali, A.; Küçüköz, B.; Hayvali, M. Inorg. Chem. 2015, 54, 7803. (b) Sabatini, R. P.; Zheng, B.; Fu, W.-F.; Mark, D. J.; Mark, M. F.; Hillenbrand, E. A.; Eisenberg, R.; McCamant, D. W. J. Phys. Chem. A 2014, 118, 10663.

(25) Zhang, X.; Chi, Z.; Zhang, Y.; Liu, S.; Xu, J. J. Mater. Chem. C 2013, 1, 3376.

(26) (a) Pinter, P.; Mangold, H.; Stengel, I.; Münster, I.; Strassner, T. Organometallics 2016, 35, 673. (b) Strassert, C. A.; Chien, C.-H.; GalvezLopez, M. D.; Kourkoulos, D.; Hertel, D.; Meerholz, K.; DeCola, L. Angew. Chem., Int. Ed. 2011, 50, 946.

(27) Forniés, J.; Sicilia, V.; Borja, P.; Casas, J. M.; Díez, A.; Lalinde, E.; Larraz, C.; Martín, A.; Moreno, M. T. Chem. - Asian J. 2012, 7, 2813.

(28) CrysAlisRED, CCD camera dar reduction program; Oxford Diffraction: Oxford, U.K., 2004.

(29) Otwinowski, Z.; Minor, W. In Methods in Enzymology; Carter, C. V., Jr., Sweet, R. M., Eds.; Academic Press: New York, 1997; Vol. 276A, p 307.

(30) Sheldrick, G. Acta Crystallogr., Sect. A: Found. Crystallogr. 2008, 64, 112.

(31) Beursken, P. T.; Beursken, G.; de Gelder, R.; Smits, J. M. M.; García-Granda, S.; Gould, R. O. DIRDIF2008.; Crystallography Laboratory, Radboud University Nijmegen: Nijmegen, The Netherlands, 2008.

(32) Sheldrick, G. M. Acta Crystallogr., Sect. A: Found. Adv. 2015, 71, 3.

(33) Sheldrick, G. Acta Crystallogr., Sect. C: Struct. Chem. 2015, 71, 3.

(34) Frisch, M. J.; et al. Gaussian 03, revision E.01; Gaussian Inc.: Wallingford, CT, 2004 (see the Supporting Information for the complete citation).

(35) Frisch, M. J.; et al. Gaussian 09, revision B.01; Gaussian Inc.: Wallingford, CT, 2009 (see the Supporting Information for the complete citation). 
(36) Becke, A. D. J. Chem. Phys. 1993, 98, 5648.

(37) (a) Perdew, J. P.; Burke, K.; Ernzerhof, M. Phys. Rev. Lett. 1996,

77, 3865. (b) Adamo, C.; Barone, V. J. Chem. Phys. 1999, 110, 6158.

(c) Perdew, J. P.; Kurth, S.; Zupan, A.; Blaha, P. Phys. Rev. Lett. 1999,

$82,2544$.

(38) Wadt, W. R.; Hay, P. J. J. Chem. Phys. 1985, 82, 284.

(39) Barone, V.; Cossi, M. J. J. Phys. Chem. A 1998, 102, 1995. 